Board of Governors of the Federal Reserve System

\author{
International Finance Discussion Papers
}

Number 836

August 2005

Estimating Elasticities for U.S. Trade in Services

Jaime Marquez

NOTE: International Finance Discussion Papers are preliminary materials circulated to stimulate discussion and critical comment. References in publications to International Finance Discussion Papers (other than an acknowledgment that the writer has had access to unpublished material) should be cleared with the author or authors. Recent IFDPs are available on the Web at www.federalreserve.gov/pubs/ifdp/. 


\title{
Estimating Elasticities for U.S. Trade in Services
}

\author{
Jaime Marquez ${ }^{*}$
}

\begin{abstract}
Explanations of the persistent deficit in U.S. net exports of goods rest on macroeconomic developments and an asymmetry in elasticities: the income elasticity for imports being larger than the income elasticity for exports. Such macroeconomic developments are not applicable to the equally persistent surplus in U.S. net exports of services unless the income elasticities for services exhibit the reversed asymmetry. There have been surprisingly few attempts to demonstrate the existence of this reversed asymmetry, a task that I undertake here. Specifically, I estimate income and price elasticities for U.S. trade in services and evaluate the importance of simultaneity and aggregation biases. The analysis reveals two findings. First, the income elasticity for U.S. exports of services is significantly greater than the income elasticity for U.S. imports of services. Second, disaggregation is the most important aspect of econometric design in this area.
\end{abstract}

JEL classification: C52, C63, C87, F17, F32

Keywords: U.S. Service Trade, External Imbalances, Income Elasticity, Price Elasticity, General-toSpecific, Automated Specification.

* Corresponding author's e-mail address is jaime.marquez@frb.gov Previous versions of this paper have been presented at the Federal Reserve Board, George Mason University, Johns Hopkins-SAIS, the 2004 Meetings of the International Economics and Finance Society and of the Midwest International Economics Group, the World Bank, the Woodrow Wilson Center, and the 2005 meetings of the Computer in Economics and Finance Society. I would like to thank Neil Ericsson, Joe Gagnon, Dale Henderson, David Hendry, Cathy Mann, and Trevor Reeve for their detailed comments. The calculations are based on PcGets; see Hendry and Krolzig (2001) and PcGive; see Hendry and Doornik (1999). The views in this paper are solely the responsibility of the authors and should not be interpreted as reflecting the views of the Board of Governors of the Federal Reserve System or of any other person associated with the Federal Reserve System. This paper can be downloaded without charge from Social Science Research Network electronic library at http://www.ssrn.com/ . 


\section{Contents}

1 Introduction and Conclusion $\quad 1$

2 External Balances and Trade Elasticities 2

3 Econometric Design 3

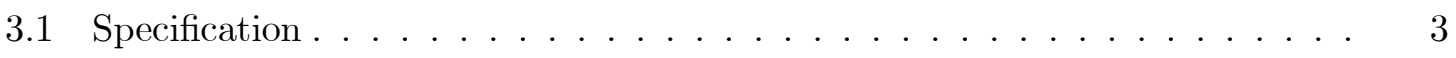

3.2 Estimation: Automated Specification . . . . . . . . . . . . . 5

3.3 Data Sources and Definitions . . . . . . . . . . . . . . 6

4 Estimation Results $\quad 7$

4.1 Gains from Automation . . . . . . . . . . . . . . . 8

4.2 Gains from Full Information Estimation . . . . . . . . . . . . . . . . 9

4.3 Gains from Disaggregation . . . . . . . . . . . . . . . . . 9

\section{Introduction and Conclusion}

Explanations of the persistent deficit in U.S. net exports of goods rest on macroeconomic developments and an asymmetry in elasticities: the income elasticity for imports being larger than the income elasticity for exports. ${ }^{1}$ Those explanations cannot, however, account for the equally persistent surplus in net exports of services unless the elasticities for service trade exhibit the reversed asymmetry: the income elasticity for exports being larger than the income elasticity for imports. This reversed asymmetry is central to reconciling macroeconomic developments with the divergence of U.S. external balances (figure 1) but there have been surprisingly few attempts to document its existence. ${ }^{2}$ Finding out whether this reversed asymmetry is supported by the data is what I do here.

Interest in estimating elasticities for trade in services extends beyond questions of external imbalances. Indeed, services and goods differ in nature and thus the available elasticity estimates for trade in goods need not be relevant for understanding the behavior of trade in services. ${ }^{3}$ For example, the production and delivery of services coincide and thus previous work characterizing dynamic adjustments for trade in goods need not extend to trade in services. Further, the scope for differentiation in services is greater than in goods (e.g., insurance policies versus oil), a feature that enhances the scope for price discrimination in services. Econometrically, differentiation means that data disaggregation and price endogeneity are relevant for estimating elasticities for trade in services.

Accordingly, I estimate income and price elasticities for exports and imports of four categories: travel, fares, transportation, and other private services. To assess aggregation

\footnotetext{
${ }^{1}$ See Bryant, Holtham, and Hooper (1988), Burger (1989), and Mann (1999, 2004).

${ }^{2}$ The key studies are Reeve (2001); Deardorff et al. (2001); Mann (2004); and Kimura and Lee (2004).

${ }^{3}$ See van Welsum (2003), and Mirza and Nicoletti (2004).
} 
biases, I compare these elasticities to the ones associated with aggregate services. I assess simultaneity biases by comparing estimates from three estimation methods: ordinary least squares, instrumental variables, and full information maximum likelihood. For modeling dynamic adjustments, I implement a General-to-Specific strategy based on the automated search algorithm developed by Krolzig and Hendry (2001). A key feature of their algorithm is that it adjusts the significance levels of statistical tests to recognize the joint nature of model specification and parameter estimation.

Two conclusions emerge from this investigation. First, the income elasticity for U.S. exports of services is significantly greater than the income elasticity for U.S. imports of services. This reversed asymmetry means that one can reconcile macroeconomic developments with the divergence in U.S. external balances. Second, disaggregation is central to this reversed asymmetry: No disaggregation means no reversed elasticity asymmetry, regardless of estimation method and specification technique.

\section{External Balances and Trade Elasticities}

The framework currently used to explain external imbalances assumes that foreign and domestic products are imperfect substitutes and that income and real exchange rates are the proximate determinants of international trade. With these assumptions, net exports of goods, $N X^{g}$, are expressed as

$$
N X_{t}^{g}=X_{t}^{g}\left(Y_{t}^{*}, Q_{t}\right)-M_{t}^{g}\left(Y_{t}, Q_{t}\right)
$$

where $X^{g}$ denotes exports of goods; $Y^{*}$ denotes foreign real income; $Q$ denotes the real effective value of the dollar; $M^{g}$ denotes imports of goods; and $Y$ denotes U.S. real income. To quantify the importance of these variables on net exports, the change of $N X_{t}^{g}$ is expressed in terms of trade elasticities and growth rates:

$$
d N X_{t}^{g}=X_{t-1}^{g} \cdot\left(\eta_{x}^{g} \cdot \widehat{Y}_{t}^{*}+\varepsilon_{x}^{g} \cdot \widehat{Q}_{t}\right)-M_{t-1}^{g} \cdot\left(\eta_{m}^{g} \cdot \widehat{Y}_{t}+\varepsilon_{m}^{g} \cdot \widehat{Q}_{t}\right),
$$

where the symbol “`, stands for growth rate, $\eta_{x}^{g}$ is the income elasticity for exports, $\varepsilon_{x}^{g}$ is the price elasticity of exports, $\eta_{m}^{g}$ is the income elasticity for imports, and $\varepsilon_{m}^{g}$ is the price elasticity for imports.

One can simplify equation (2) further by recognizing two properties of the data. First, since 1970, the average rate of change of the real effective value of the dollar has been close to zero (figure 1 ) and thus I set $\widehat{Q}_{t}=0$. Second, prior to 1976, net exports of goods were balanced meaning that $X_{t-1}^{g}=M_{t-1}^{g} \cdot{ }^{4}$ With these properties, equation (2) becomes

$$
d N X_{t}^{g}=X_{t-1}^{g} \cdot\left[\left(\eta_{x}^{g} \cdot \widehat{Y}_{t}^{*}-\eta_{m}^{g} \cdot \widehat{Y}_{t}\right)\right]
$$

\footnotetext{
${ }^{4}$ Net exports of goods and net exports of services were quite close to zero from 1930 to 1976.
} 
Equation (3) has implications for the pattern of income elasticities. Specifically, as figure 1 shows, growth in the rest of the world has been, on average, quite close to that of the United States. ${ }^{5}$ Thus reconciling $\widehat{Y}_{t}^{*} \approx \widehat{Y}_{t}$ with $d N X^{g}<0$ implies that $\eta_{x}^{g}<\eta_{m}^{g}$, an asymmetry with ample empirical support. ${ }^{6}$

Though coherent, this framework cannot account for the persistent surplus in net exports of services. Indeed, if one uses real income and real exchange rates to explain services, then the change in net exports of services, $d N X_{t}^{s}$, can be written as

$$
d N X_{t}^{s}=X_{t-1}^{s} \cdot\left[\left(\eta_{x} \cdot \widehat{Y}_{t}^{*}-\eta_{m} \cdot \widehat{Y}_{t}\right)\right]
$$

where $X^{s}$ denotes exports of services; $\eta_{x}$ is the income elasticity for exports of services; and $\eta_{m}$ is the income elasticity for imports of services. Thus reconciling $\widehat{Y}_{t}^{*} \approx \widehat{Y}_{t}$ with $d N X^{s}>0$ implies that $\eta_{x}>\eta_{m}$. The question I address is whether the data support this reversed asymmetry.

\section{Econometric Design}

The empirical formulation rests on the imperfect substitute model in which movements in the logarithm of trade are explained in terms of movements in the logarithms of income and relative prices. ${ }^{7}$ To allow for delayed responses, induced perhaps by service contracts, I use an autoregressive distributed lag formulation.

\subsection{Specification}

The specification for exports of the ith type of services is

$$
\left(1-\theta_{1 i}(L)\right) \ln x_{i t}=\theta_{0 i}+\theta_{2 i}(L) \ln \left(\frac{P_{x i t}}{P_{t}^{*}}\right)+\theta_{3 i}(L) \ln Y_{t}^{*}+u_{x i t}, u_{x i t} \sim I N\left(0, \sigma_{x i}^{2}\right)
$$

where $x_{i}$ denotes real exports of services of the $i t h$ category; $P_{x i}$ denotes the dollar export price of the $i t h$ category of services; $P^{*}$ denotes the foreign price deflator expressed in U.S. dollars; $\theta_{k i}(L)=\sum_{j=0}^{\ell_{x}} \theta_{k i j} L^{j}(k>0)$ where $L$ is the lag operator. The long-run income elasticity is

$$
\eta_{x i}=\frac{\theta_{3 i}(1)}{1-\theta_{1 i}(1)}>0
$$

and the long-run price elasticity is $\varepsilon_{x i}=\frac{\theta_{2 i}(1)}{1-\theta_{1 i}(1)}<0$.

\footnotetext{
${ }^{5}$ One cannot reject the hypothesis that $E\left(\widehat{Y}_{t}^{*}\right)=E\left(\widehat{Y}_{t}\right)$.

${ }^{6}$ This asymmetry was noted first by Houthakker and Magee in 1969; Goldstein and Khan (1985) and Marquez (2002) review the associated literature. Recent papers on this asymmetry were presented at the 2004 ASSA meetings in the session "Income and Price Elasticities in World Trade: 35 Years Later."

${ }^{7}$ The most common formulation in this area is the log-linear one; see Goldstein and Khan (1985) and Marquez (2002).
} 
Having estimated the long-run elasticities across export categories, I aggregate them into an elasticity for aggregate exports. For the income elasticity, the aggregate is

$$
\eta_{x t}^{d}=\sum_{i} \mu_{i t} \cdot \eta_{x i}
$$

where $\mu_{i t}$ is the export share of the ith type of service exports and the superscript ' $d$ ' denotes an aggregate elasticity based on disaggregated equations; I construct a comparable aggregate for the price elasticities.

As an alternative to equation (7), I estimate elasticities for aggregate exports as such:

$$
\left(1-\theta_{1}(L)\right) \ln x_{t}=\theta_{0}+\theta_{2}(L) \ln \left(\frac{P_{x t}}{P_{t}^{*}}\right)+\theta_{3}(L) \ln Y_{t}^{*}+u_{x t}, u_{x t} \sim I N\left(0, \sigma_{x}^{2}\right)
$$

where $x$ denotes aggregate exports of services in real terms, $P_{x t}$ denotes the dollar export price of aggregate services, and $\theta_{i}(L)=\sum_{j=0}^{\ell_{x}} \theta_{i j} L^{j}(i>0)$. The long-run income elasticity is

$$
\eta_{x}^{a}=\frac{\theta_{3}(1)}{1-\theta_{1}(1)}>0
$$

and the associated long-run price elasticity is $\varepsilon_{x}^{a}=\frac{\theta_{2 i}(1)}{1-\theta_{1 i}(1)}<0$; the superscript ' $a$ ' denotes an aggregate elasticity based on an aggregate equation. With two alternative estimates of the aggregate income elasticity, I assess the importance of aggregation bias by testing whether $\eta_{x}^{a}$ is significantly different from $\eta_{x}^{d}$; I apply the same test to the price elasticities.

The specification for imports of the $i t h$ type of services is

$$
\left(1-\phi_{1 i}(L)\right) \ln m_{i t}=\phi_{0 i}+\phi_{2 i}(L) \ln \left(\frac{P_{m i t}}{P_{t}}\right)+\phi_{3 i}(L) \ln Y_{t}+u_{m i t}, u_{m i t} \sim I N\left(0, \sigma_{m i}^{2}\right)
$$

where $m_{i}$ denotes real imports of the $i t h$ type of service; $P_{m i}$ denotes the dollar import price of services; $P$ denotes the U.S. GDP deflator; $\phi_{k i}(L)=\sum_{j=0}^{\ell_{m}} \phi_{k i j} L^{j}(k>0)$. The long-run income elasticity is

$$
\eta_{m i}=\frac{\phi_{3 i}(1)}{1-\phi_{1 i}(1)}>0
$$

and the long-run price elasticity is $\varepsilon_{m i}=\frac{\phi_{2 i}(1)}{1-\phi_{1 i}(1)}<0$. The aggregate of the income elasticities is

$$
\eta_{m t}^{d}=\sum_{i} \omega_{i t} \cdot \eta_{m i}
$$

where $\omega_{i t}$ is the import share of the $i t h$ type of service imports; I construct a comparable aggregate for the price elasticities.

The corresponding specification for aggregate imports of services is

$$
\left(1-\phi_{1}(L)\right) \ln m_{t}=\phi_{0}+\phi_{2}(L) \ln \left(\frac{P_{m t}}{P_{t}}\right)+\phi_{3}(L) \ln Y_{t}+u_{m t}, u_{m t} \sim I N\left(0, \sigma_{m}^{2}\right)
$$


where $m$ represents aggregate imports of services in real terms; $P_{m t}$ denotes the dollar import price of aggregate services; and $\phi_{i}(L)$ is a polynomial in the lag operator $L$. The long-run income elasticity of aggregate imports is

$$
\eta_{m}^{a}=\frac{\phi_{3}(1)}{1-\phi_{1}(1)}>0
$$

and the long-run price elasticity is $\varepsilon_{m}^{a}=\frac{\phi_{2}(1)}{1-\phi_{1}(1)}<0$. Again, I assess the magnitude of the aggregation bias in the estimated income elasticity by testing whether $\eta_{m}^{a}$ is significantly different from $\eta_{m t}^{d}$; I apply the same test to the aggregate of price elasticities.

\subsection{Estimation: Automated Specification}

The automated-specification algorithm developed by Hendry and Krolzig (2001) offers three advantages relative to implementing a General-to-Specific strategy interactively. ${ }^{8}$ First, their algorithm considers all of the statistically valid specifications. Second, the algorithm adjusts the significance levels for statistical tests to recognize the joint nature of model specification and parameter estimation. Finally, each step in the process of automated search can be replicated at once.

The algorithm combines least squares with a selection strategy that is implemented in four stages: ${ }^{9}$

1. Estimate the parameters of a general formulation - equation (5) for example- and test for congruency (white-noise residuals).

2. Implement multiple "simplification paths" simultaneously. One simplification path could get started by excluding the least significant variable whereas another simplification path could get initiated by excluding a block of variables that are jointly insignificant.

3. Test whether the specification from a simplification path is congruent. If it is, then implement another round of simplifications and re-test for congruency; continue this process until the specification violates congruency. In that case, the algorithm selects the immediately prior specification and labels it Final model.

4. Collect the Final models from all simplification paths and apply encompassing tests to them. The specification that encompasses all others becomes the Specific model. If there is no single encompassing model, then the algorithm forms a "union" model using the variables from all of the Final models and re-starts the specification search from step (2). If this strategy fails to yield a single Specific model, then the algorithm

\footnotetext{
${ }^{8}$ For a discussion of the issues raised by automated specification, see Hendry and Krolzig (2003), Granger and Hendry (2004), and Phillips (2004).

${ }^{9} \mathrm{I}$ use Package version 1.02 of PcGets with its default settings.
} 
applies three information criteria (Akaike, Schwarz, and Hannan-Quinn) to the Final models and selects the one that minimizes all these criteria; that model becomes the Specific model. ${ }^{10}$ Otherwise, the algorithm fails to find a Specific model.

I implement these steps following two automated strategies. In the first one, labeled Liberal, the cost of excluding a relevant variable is deemed higher than the cost of retaining an irrelevant variable; thus the algorithm errs on the side of retaining additional variables in the specification. In the second one, labeled Conservative, the cost of including irrelevant variables is deemed higher than the cost of excluding relevant variables; thus the algorithm errs on the side of excluding relevant variables.

\subsection{Data Sources and Definitions}

I disaggregate data for services into their four components: travel, fares, transportation, and other private services. ${ }^{11}$ Data for travel exports are receipts from foreign residents on food, lodging, recreation, gifts, and local transportation; travel imports are payments to foreign residents on the same groupings. Data for fare exports are expenditures by foreign travelers to U.S. carriers; fare imports are payments by U.S. residents to foreign carriers and foreign cruise operators. Data for transportation exports are receipts from foreign residents on freight services for ocean, air, rail (Canada and Mexico); data for transportation imports are expenses by shippers in foreign ports and payments to foreign residents for vessel charters, aircraft rentals, and freight-car rentals. Data for exports of other private services are receipts for education, financial services, insurance, telecommunications, business, and other. ${ }^{12}$ Data for imports of other private services are payments by U.S. residents to foreign residents on the same six categories.

I measure the relative import price of the $i t h$ category as $\frac{P_{m i t}}{P_{t}}$ where $P_{m i}$ is the chain weighted price index for imports of the $i t h$ category and $P$ is the chain weighted price for GDP; the data come from the BEA. I measure the relative price of exports of the ith category as $\frac{P_{x i t}}{P_{t}^{*}}$ where $P_{x i t}$ is BEA's chain weighted export price index for the $i t h$ category

\footnotetext{
${ }^{10}$ There is no guarantee that reliance on these three criteria will yield a unique model. In the event that the application of these criteria yields more than one model, the user specifies a criteria ranking to settle the conflict. In this paper, I use the Akaike Information Criterion.

${ }^{11}$ All of the data for services, both in current and constant prices come from the Survey of Current Business prepared by the Bureau of Economic Analysis (BEA). The data for trade in real terms begin in 1987. The components for Defense and Royalties are excluded as they do not involve arm's length negotiations. These components represent a small share of the aggregate services.

${ }^{12}$ Education: expenditures by foreign students in the United States. Financial services: commissions and transactions fees associated with purchases of U.S. securities. Telecommunications: telephone services, telex, e-mails, management of data networks and satellites' information. Business: receipts for services provided in accounting, auditing, bookkeeping, advertising, computer and data processing, engineering, architectural, legal, consulting, medical services, performing arts, sport events. Other: film and tape rentals, earnings of U.S. residents temporarily employed abroad, expenditures of foreign residents employed temporarily in the United States, expenditures by international organizations in the United States.
} 
of services, and $P^{*}$ is the foreign deflator in dollars. I measure this deflator as

$$
P_{t}^{*}=\prod_{j}\left(P_{j t} \cdot E_{\$ / j, t}\right)^{\gamma_{j t}}, \sum_{j} \gamma_{j t}=1
$$

where $E_{\$ / j}$ is the nominal, bilateral rate of the dollar against the $j$ th currency; $P_{j}$ is the deflator for the $j t h$ country in local currency; $\gamma_{j t}$ is the time-varying share of country $j$ in U.S. bilateral exports of services to 36 countries. ${ }^{13}$

I measure U.S. GDP with BEA's chain weighted measure of GDP in constant prices; I measure foreign real GDP as

$$
Y_{t}^{*}=\prod_{j} Y_{j t}^{\gamma_{j t}}, \sum_{j} \gamma_{j t}=1
$$

where $Y_{j}$ is an index of the real GDP of the $j t h$ country.

For disaggregation to matter, relative prices should exhibit different trends and trade shares should change in relative importance. Figure 2 shows that these conditions are met for U.S. trade in services. For example, the relative price for imports of other private services declines steadily whereas the relative prices for imports of fares rises steadily. Further, travel exports had, until 1996, the largest share of total exports of services, exceeding 30 percent. Since then, exports of other private services have become the category with the largest share: nearly 45 percent in 2001 . The counterpart to this increase is the decline in the export share of other transportation services: from 20 percent to 10 percent.

\section{Estimation Results}

Using quarterly observations from 1987 to 2001, I obtain elasticity estimates for the general and specific formulations (liberal and conservative). To address the question of how "general is the general model," I use alternative general models that differ solely in their lag lengths: 4, 6, and 8 quarters. For each specification, I test for congruency (residuals exhibiting normality, serial independence, and homoskedasticity). To explore the role of estimation methods, I use ordinary least squares (OLS), instrumental variables (IV), and Johansen's full information maximum likelihood (FIML) procedure. ${ }^{14}$

Table 1 reports OLS and IV estimates for selected specifications. ${ }^{15}$ Specifically, for each estimator and search strategy, I select the estimates from the congruent specification with

\footnotetext{
${ }^{13} 20$ OECD countries (including Mexico and South Korea), China, Argentina, Brazil, Chile, Colombia, Venezuela, Hong Kong, India, Indonesia, Malaysia, Philippines, Singapore, Taiwan, Thailand.

${ }^{14}$ For instruments I use the lagged ratio of U.S. claims on foreigners relative to U.S. GDP, the lagged ratio of U.S. liabilities to foreigners to U.S. GDP, the price of domestic services, contemporaneous and lagged; I have not evaluated the results to alternative instruments. For Johansen's procedure, see Johansen (1988).

${ }^{15}$ Release 1.02 of PcGets allows only OLS and IV. For these two estimators, there are 18 specifications for each type of service: three maximum lag-lengths $(4,6,8)$, three search strategies (general, liberal, conservative), and two estimators (OLS, IV).
} 
the smallest standard error of the regression; the appendix reports detailed results for each specification. ${ }^{16}$ The results reveal three findings of interest. First, estimated elasticities vary greatly across types of services. For example, the IV estimates of the income elasticity for imports range from 0.4 (significant) for transportation to 2.5 (significant) for other private services; the corresponding price elasticities range from zero for transportation to -2.1 (significant) for other private services; the dispersion of estimates across categories is robust to changes in econometric design. Second, for a given service category, the estimated income elasticity is robust to changes in econometric design. This robustness extends to the income elasticity of aggregate imports but not to the income elasticity of aggregate exports. Third, with the exception of travel services, estimated price elasticities are quite sensitive to changes in econometric design. For travel, the price elasticity for exports ranges from -0.7 to -0.8 , both significant; the price elasticity for travel imports ranges from -1.3 to -1.5 , both significant.

\subsection{Gains from Automation}

A complete assessment of the gains from pursuing automated specification involves replicating previous work not based on automation, a task that is beyond this paper. Nevertheless, an interesting question is whether the absence of automation yields an empirical model that is consistent with theory. In the context of this paper, the question is whether the estimates from the general specification are consistent with the predictions from the imperfect-substitute model. For aggregate exports, the IV estimates of the general model exhibit an income elasticity of zero whereas estimation based on automated search yields an income elasticity greater than one (table 1). For exports of other private services, the only instances of negative price elasticities involve automated search: without it, the results would not support the imperfect substitute model.

Estimates for travel appear, however, invariant to the use of automation. Specifically, as shown in table A-10 of the appendix, the long-run income elasticity for travel imports is 1.1 whereas the associated long-run price elasticity varies from -1.3 to -1.5, a narrow range. One possible explanation for this seemingly irrelevant role of automation is my focus on long-run elasticities at the expense of other properties such as the nature of dynamic adjustments. To this end, I study how the elasticities' cumulative lag distributions change in response to a change in the specification strategy. An elasticity's cumulative lag distribution is the ratio between the value the elasticity takes $q$ quarters into an adjustment process and the value this elasticity takes in the long run. ${ }^{17}$ A ratio of two after $q$ quarters, for example, indicates that the elasticity estimate after $q$ quarters is twice as large as the value it will

\footnotetext{
${ }^{16}$ Figures A1-A5 compare estimates across lags, estimation methods, and search strategies; tables A1-A10 indicate whether these specifications exhibit normality, serial independence, and homoskedasticity. These tables include key statistics comparing the general and the specific formulation: standard errors, number of parameters, maximum lag in the specification.

${ }^{17}$ See Hendry and Doornik (1999), page 237 for the formal derivation of the cumulative lag distribution.
} 
have in the long run.

Figure 3 shows the cumulative lag distributions for travel imports when the general model has eight lags. ${ }^{18}$ The results reveal that, in the absence of automated search, the dynamic adjustment has large and frequent oscillations. For example, the cumulative lag distribution for the income elasticity has a value of 2.5 after five quarters followed by a value of 0.2 after eight quarters. Such large oscillations are, however, dampened considerably using automated specification. The figure also reveals that reliance on automated search shortens the adjustment delay. For example, the estimates from the general formulation suggest that reaching the long-run income elasticity takes more than 40 quarters whereas the estimated delay from a conservative search strategy is ten quarters.

Overall, relying on a general model with no (automated) simplification has two drawbacks for explaining trade in services. First, the elasticity estimates do not support the imperfect-substitute model. Second, the dynamic adjustment for travel imports is implausibly slow.

\subsection{Gains from Full Information Estimation}

Table 2 compares the FIML estimates to those of table $1 .{ }^{19}$ From an econometric standpoint, the most significant result is that the difference between IV and OLS estimates is negligible when compared to the difference between IV and FIML estimates. In other words, just using IV estimation suggests that simultaneity biases are small when they are not. From an economic standpoint, the most important result is that the FIML estimates for the income elasticities of aggregate equations do not exhibit a reversed asymmetry: 1.3 for exports and 1.6 for imports. This finding implies that either the imperfect-substitute model is inconsistent with the surplus in net exports of services or that aggregation biases conceal a reversed asymmetry in income elasticities.

\subsection{Gains from Disaggregation}

Table 2 suggests that aggregation biases could indeed be concealing a reversed asymmetry in income elasticities: the estimates for disaggregated exports are generally greater than the corresponding income elasticities for imports. ${ }^{20}$ To explore this possibility further, figure 4 displays the 95 percent confidence bands for the income elasticity based on the disaggregated estimates $\left(\eta_{x t}^{d}, \eta_{m t}^{d}\right)$ and based on the aggregate estimates $\left(\eta_{x}^{a}, \eta_{m}^{a}\right)$. The most important finding is that, based on the disaggregate estimates, the income elasticity for aggregate exports is significantly higher than the income elasticity for aggregate imports. Furthermore, the existence and statistical significance of this reversed asymmetry are not

\footnotetext{
${ }^{18}$ Figures A6-A7 in the appendix show the cumulative lag distribution of the cases of six and four lags.

${ }^{19}$ Tables A1-A10 report the cointegration vector, the number of cointegration vectors, the speed of adjustment (loading coefficient), and the test results for the properties of the vector of residuals.

${ }^{20}$ Figures A8-A11 of the appendix compare the aggregate of elasticities to the elasticity of the aggregate and the tests confirm the existence of aggregation biases in income and price elasticities.
} 
sensitive to the estimation method. For example, the FIML estimates of $\eta_{x t}^{d}$ and $\eta_{m t}^{d}$ are 2.5 and 1.1, respectively, quite comparable to the reversed asymmetry for the OLS and IV estimates. The second important finding is that the elasticity estimates based on the aggregate equation do not exhibit such a reversal, regardless of estimation method. In other words, estimating the parameters of equations for aggregate service yields empirical models that, though supported by tests of statistical adequacy, cannot reconcile macroeconomic developments with the divergence in U.S. external balances. Overall, then, disaggregation is central to accounting for the divergence in the U.S. external balances with the imperfect substitute model.

\section{References}

[1] Bryant, R., G. Holtham, and P. Hooper, 1988, External Deficits and the Dollar, Washington, DC: Brookings Institution.

[2] Burger, A. (ed.), 1989, U.S. Trade Deficit: Causes, Consequences, and Cures, Boston, MA: Kluwer Academic Press.

[3] Deardorff, A., S. Hymans, R. Stern, and C. Xiang, 2001, "Forecasting U.S. Trade in Services," in R. Stern, ed., Services in the International Economy: Measurement and Modeling, Sector and Country Studies, and Issues in the WTO Services Negotiations, Ann Arbor: University of Michigan Press.

[4] Goldstein, M. and M. Khan, 1985, "Income and Price Effects in Foreign Trade," in R. Jones and P. Kenen (eds.), Handbook of International Economics, Amsterdam: NorthHolland.

[5] Granger, C. and D. H. Hendry, 2004, "A Dialogue Concerning a New Instrument for Econometric Modeling," Econometric Theory, forthcoming.

[6] Hendry, D. F. and J. Doornik, 1999, Empirical Econometric Modelling Using PcGive, London: Timberlake.

[7] Hendry, D. F. and H. Krolzig, 2001, Automatic Econometric Model Selection Using PcGets, London: Timberlake.

[8] Hendry, D. F. and H. Krolzig, 2003, "New Developments in Automatic General-toSpecific Modeling," in B. Stigum (ed.), Econometrics and the Philosophy of Economics, Princeton: Princeton University Press.

[9] Houthakker, H. and S. Magee, 1969, "Income and Price Elasticities in World Trade," Review of Economics and Statistics, 51, 111-125. 
[10] Johansen, S., 1988, "Statistical Analysis of Cointegration Vectors," Journal of Economic Dynamics \&3 Control, 12, 231-254.

[11] Kimura, F. and H. Lee, 2004, "The Gravity Equation in International Trade in Services," Kangwon National University, mimeo.

[12] Mann, C., 1999, Is the U.S. Trade Deficit Sustainable? Washington DC: Institute for International Economics.

[13] Mann, C., 2004, "The US Current Account, New Economy Services, and Implications for Sustainability," Review of International Economics, 12, 262-276.

[14] Marquez, J., 2002, Estimating Trade Elasticities, Dordrecht: Kluwer Academic Publishers.

[15] Mirza, D. and G. Nicoletti, 2004, "Is there Something Special About Trade in Services?" OECD, mimeo.

[16] Phillips, P., 2004, "Automated Discovery in Econometrics," Cowles Foundation Discussion Paper No. 1469, New Haven, Yale University.

[17] Reeve, T., 2001, "Trade in Services," Federal Reserve Board, mimeo.

[18] van Welsum, D., 2003, "International Trade in Services: Issues and Concepts," Birkbeck College London, mimeo. 


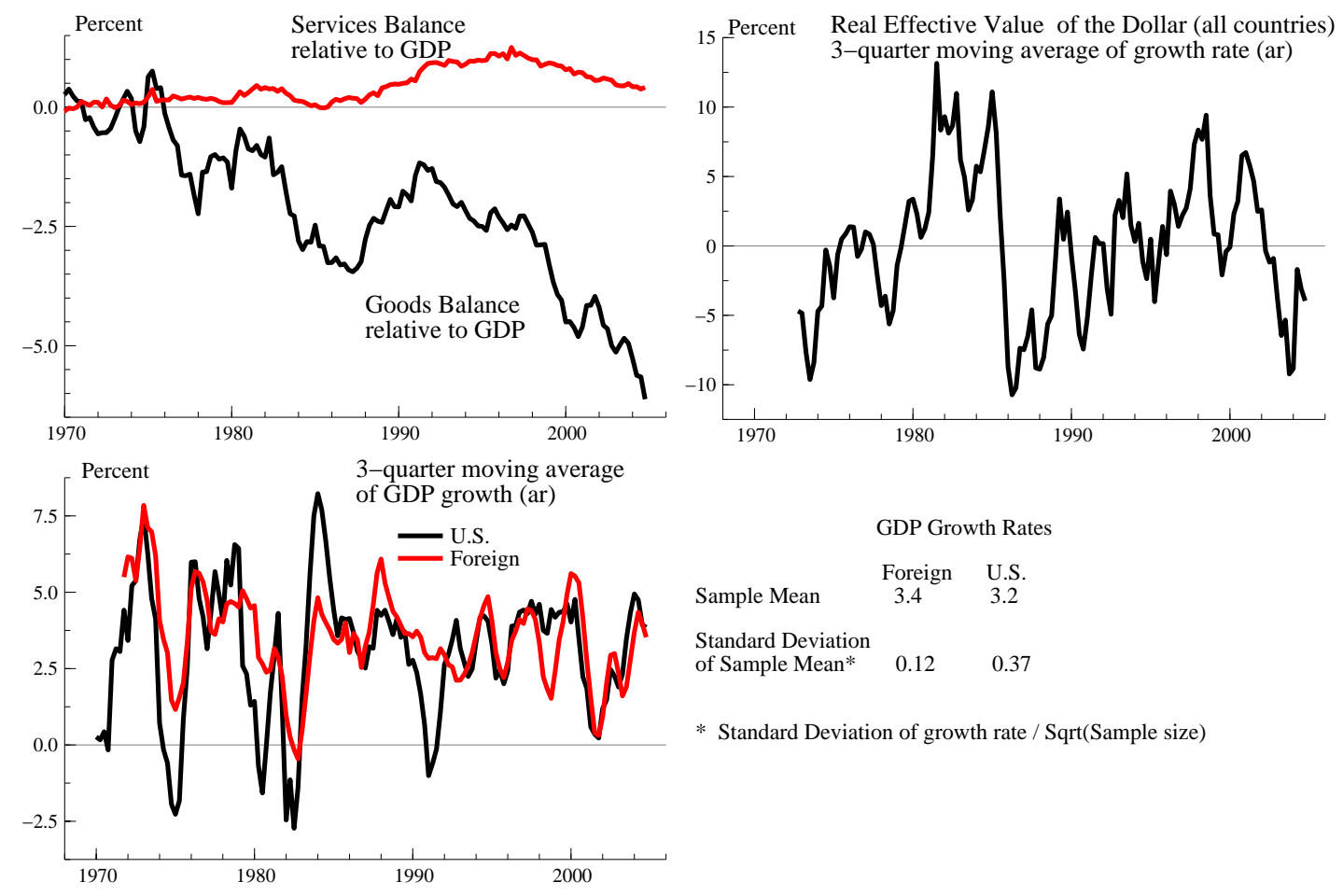

Figure 1: U.S. External Balances, Incomes, and the Real Exchange Rate 

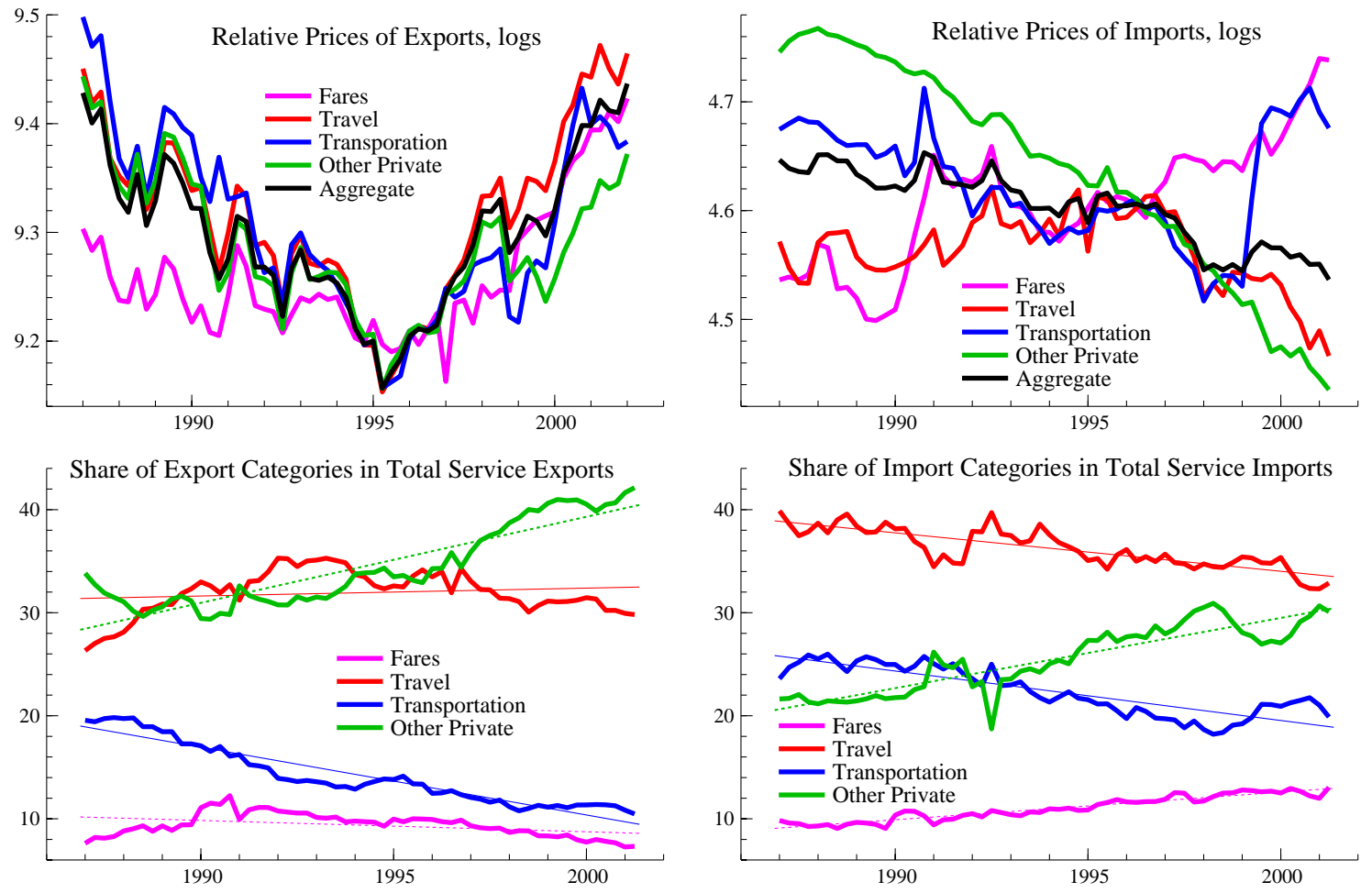

Figure 2: Relative Prices and Trade Shares for U.S. Trade in Services 

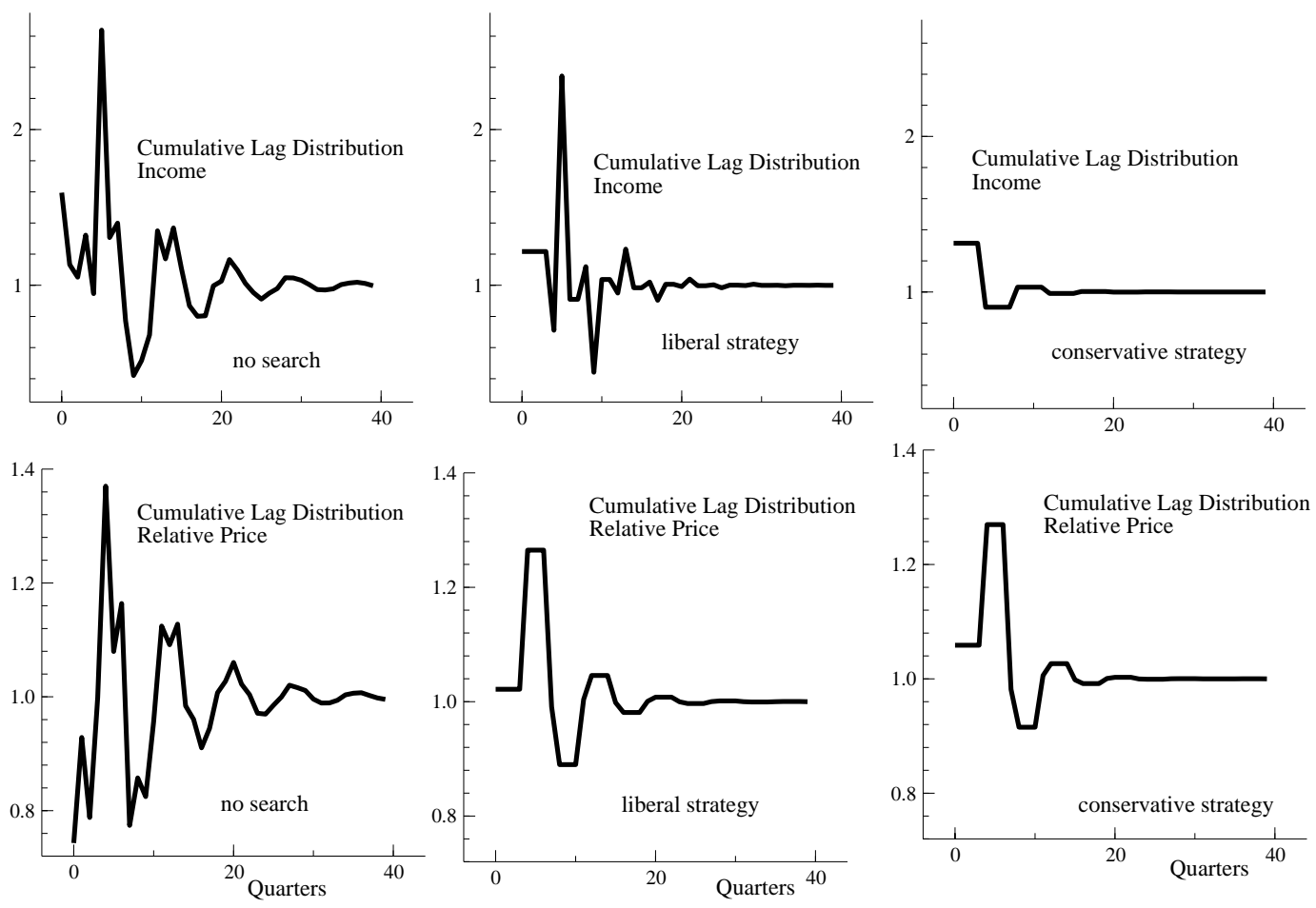

Figure 3: Cumulative Lag Distributions for OLS Elasticities of Travel Imports-8 lags 

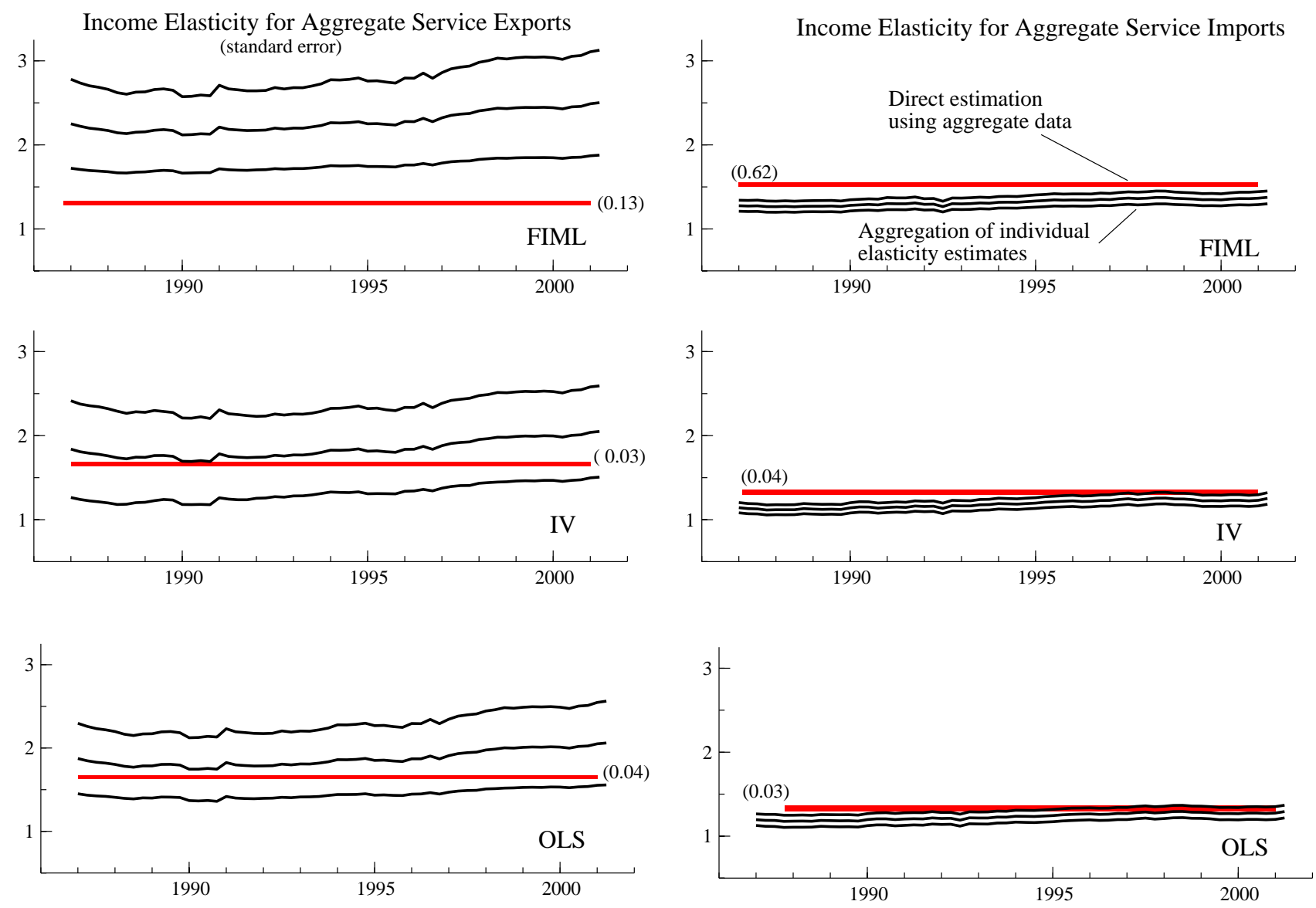

Figure 4: Income Elasticities for Aggregate Services-Sensitivity to Estimation Method 
Income Elasticity

Table 1: Long-run Elasticities for Trade in Services Sensitivity to Single-Equation Estimation Method Selected Specifications ${ }^{\text {a }}$

\begin{tabular}{|c|c|c|c|c|c|c|c|c|}
\hline \multirow[b]{3}{*}{ Category } & \multicolumn{4}{|c|}{ Exports } & \multicolumn{4}{|c|}{ Imports } \\
\hline & \multicolumn{2}{|c|}{ OLS } & \multicolumn{2}{|c|}{ IV } & \multicolumn{2}{|c|}{ OLS } & \multicolumn{2}{|c|}{ IV } \\
\hline & General $^{b}$ & Specific $^{c}$ & General & Specific & General & Specific & General & Specific \\
\hline Other Private & $3.23 *$ & $3.12 *$ & $3.26^{*}$ & $3.20 *$ & 2.26 & $1.54 *$ & 2.18 & $1.50^{*}$ \\
\hline Fares & 0.40 & 0.59 & 0.10 & 0.00 & $2.12 *$ & $2.36^{*}$ & $2.12 *$ & $2.47 *$ \\
\hline Transportation & $0.92 *$ & $0.99 *$ & $1.12 *$ & $0.86^{*}$ & 0.73 & $0.65 *$ & 0.73 & $0.36^{*}$ \\
\hline Travel & $1.48^{*}$ & $1.30^{*}$ & $1.12 *$ & $1.32 *$ & $1.07^{*}$ & $1.08^{*}$ & $1.09 *$ & $1.09 *$ \\
\hline Aggregate Trade & $1.29 *$ & $1.67 *$ & 0.00 & $1.69 *$ & $1.47 *$ & $1.37 *$ & $1.37 *$ & $1.36^{*}$ \\
\hline
\end{tabular}

Price Elasticity

\begin{tabular}{|c|c|c|c|c|c|c|c|c|}
\hline \multirow[b]{3}{*}{ Category } & \multicolumn{4}{|c|}{ Exports } & \multicolumn{4}{|c|}{ Imports } \\
\hline & \multicolumn{2}{|c|}{ OLS } & \multicolumn{2}{|c|}{ IV } & \multicolumn{2}{|c|}{ OLS } & \multicolumn{2}{|c|}{ IV } \\
\hline & General & Specific & General & Specific & General & Specific & General & Specific \\
\hline Other Private & +0.48 & $-1.08 *$ & +0.35 & $-1.14 *$ & -1.31 & $-2.18 *$ & -1.06 & $-2.10 *$ \\
\hline Fares & -1.07 & +0.01 & $-2.02 *$ & +0.32 & $-0.62 *$ & $-1.37 *$ & -0.62 & $-1.53 *$ \\
\hline Transportation & -0.12 & $-0.17 *$ & -0.06 & $-0.09 *$ & +0.80 & $-0.53 *$ & +0.80 & 0.00 \\
\hline Travel & $-0.68 *$ & $-0.76^{*}$ & $-0.81 *$ & $-0.77 *$ & $-1.40 *$ & $-1.26^{*}$ & $-1.43 *$ & $-1.29 *$ \\
\hline Aggregate Trade & -0.50 & $-0.26^{*}$ & $-1.12 *$ & $-0.27 *$ & $-1.10^{*}$ & $-1.60 *$ & $-1.62 *$ & $-1.57 *$ \\
\hline
\end{tabular}

${ }^{a}$ Selection criteria: For the General formulation, with either OLS or IV, there are three candidates that differ in the number of lags; I report the estimates for the specification that is both congruent and has the lowest standard error of the regression. For the Specific formulation, there are six candidates for each estimation method: 3 alternative initial lags and two search strategies. Of these, I report the estimates associated with the specification that is both congruent and has the lowest standard error of the regression.

${ }^{\mathrm{b}}$ General: General Unrestricted Model; there is no search.

${ }^{\mathrm{c}}$ Specific: Outcome of the automated specification algorithm 
Table 2: Long-run Income and Price Elasticities for Exports and Imports of Services - 1987-2001 Alternative Estimation Methods - Selected Formulations**

(Standard errors)

\begin{tabular}{|c|c|c|c|c|c|c|c|c|}
\hline \multirow{3}{*}{ Category } & \multicolumn{4}{|c|}{ Exports } & \multicolumn{4}{|c|}{ Imports } \\
\hline & & & Estimation & Search & & & Estimation & Search \\
\hline & Income & Price & Method & Algorithm & Income & Price & Method & Algorithm \\
\hline \multirow[t]{3}{*}{ Aggregate } & $\begin{array}{l}1.33 * \\
(0.13)\end{array}$ & $\begin{array}{l}-0.37 \\
(0.20)\end{array}$ & FIML & NA & $\begin{array}{l}1.55^{*} \\
(0.62)\end{array}$ & $\begin{array}{l}-0.92 * \\
(0.16)\end{array}$ & FIML & NA \\
\hline & $\begin{array}{l}1.69 * \\
(0.03)\end{array}$ & $\begin{array}{c}-0.27 * \\
(0.02)\end{array}$ & IV & Liberal & $\begin{array}{l}1.36^{*} \\
(0.04)\end{array}$ & $\begin{array}{c}-1.57 * \\
(0.07)\end{array}$ & IV & Liberal \\
\hline & $\begin{array}{l}1.67 * \\
(0.04)\end{array}$ & $\begin{array}{c}-0.26^{*} \\
(0.02)\end{array}$ & OLS & Liberal & $\begin{array}{l}1.37 * \\
(0.03)\end{array}$ & $\begin{array}{c}-1.60 * \\
(0.05)\end{array}$ & OLS & Conservative \\
\hline \multirow[t]{3}{*}{ Other Private } & $\begin{array}{l}3.79 * \\
(0.65)\end{array}$ & $\begin{array}{c}-1.52 * \\
(0.32)\end{array}$ & FIML & NA & $\begin{array}{l}1.73^{*} \\
(0.10)\end{array}$ & $\begin{array}{l}-2.51 * \\
(0.19)\end{array}$ & FIML & NA \\
\hline & $\begin{array}{l}3.20 * \\
(0.51)\end{array}$ & $\begin{array}{c}-1.14 * \\
(0.26)\end{array}$ & IV & Liberal & $\begin{array}{l}1.50 * \\
(0.06)\end{array}$ & $\begin{array}{l}-2.11 * \\
(0.11)\end{array}$ & IV & Conservative \\
\hline & $\begin{array}{l}3.12 * \\
(0.52)\end{array}$ & $\begin{array}{c}-1.08 * \\
(0.26)\end{array}$ & OLS & Liberal & $\begin{array}{l}1.54 * \\
(0.08)\end{array}$ & $\begin{array}{l}-2.18 * \\
(0.15)\end{array}$ & OLS & Liberal \\
\hline \multirow[t]{3}{*}{ Fares } & $\begin{array}{l}1.11 * \\
(0.21)\end{array}$ & $\begin{array}{c}-1.43 * \\
(0.58)\end{array}$ & FIML & NA & $\begin{array}{l}2.11 * \\
(0.09)\end{array}$ & $\begin{array}{c}-0.92 * \\
(0.20)\end{array}$ & FIML & NA \\
\hline & $\begin{array}{c}0.10 \\
(0.84)\end{array}$ & $\begin{array}{l}-2.02 * \\
(1.12)\end{array}$ & IV & None & $\begin{array}{l}2.47 * \\
(0.17)\end{array}$ & $\begin{array}{c}-1.53 * \\
(0.34)\end{array}$ & IV & Liberal \\
\hline & $\begin{array}{c}0.59 \\
(0.61)\end{array}$ & $\begin{array}{c}0.01 \\
(0.30)\end{array}$ & OLS & Liberal & $\begin{array}{l}2.36^{*} \\
(0.13)\end{array}$ & $\begin{array}{c}-1.37 * \\
(0.29)\end{array}$ & OLS & Liberal \\
\hline \multirow[t]{3}{*}{ Transportation } & $\begin{array}{l}0.95 * \\
(0.27)\end{array}$ & $\begin{array}{c}-0.53 * \\
(0.36)\end{array}$ & FIML & NA & $\begin{array}{l}0.91 * \\
(0.07)\end{array}$ & $\begin{array}{l}-0.14 \\
(0.16)\end{array}$ & FIML & NA \\
\hline & $\begin{array}{l}0.86^{*} \\
(0.86)\end{array}$ & $\begin{array}{c}-0.09 * \\
(0.04)\end{array}$ & IV & Liberal & $\begin{array}{l}0.36^{*} \\
(0.01)\end{array}$ & $\begin{array}{c}0.00 \\
--\end{array}$ & IV & Liberal \\
\hline & $\begin{array}{l}0.99 * \\
(0.10)\end{array}$ & $\begin{array}{c}-0.17 * \\
(0.05)\end{array}$ & OLS & Liberal & $\begin{array}{l}0.65^{*} \\
(0.10)\end{array}$ & $\begin{array}{c}-0.53 * \\
(0.19)\end{array}$ & OLS & Conservative \\
\hline \multirow[t]{3}{*}{ Travel } & $\begin{array}{l}1.57 * \\
(0.17)\end{array}$ & $\begin{array}{c}-0.79 * \\
(0.19)\end{array}$ & FIML & NA & $\begin{array}{l}1.04 * \\
(0.03)\end{array}$ & $\begin{array}{c}-1.56^{*} \\
(0.10)\end{array}$ & FIML & NA \\
\hline & $\begin{array}{l}1.32 * \\
(0.12)\end{array}$ & $\begin{array}{c}-0.77 * \\
(0.15)\end{array}$ & IV & Conservative & $\begin{array}{l}1.09 * \\
(0.05)\end{array}$ & $\begin{array}{c}-1.43^{*} \\
(0.16)\end{array}$ & IV & None \\
\hline & $\begin{array}{l}1.30 * \\
(0.09)\end{array}$ & $\begin{array}{c}-0.76 * \\
(0.12)\end{array}$ & OLS & Conservative & $\begin{array}{l}1.08 * \\
(0.02)\end{array}$ & $\begin{array}{c}-1.26^{*} \\
(0.04)\end{array}$ & OLS & Liberal \\
\hline
\end{tabular}

NA: not applicable.

**Selection: Lowest SER among functional forms that satisfy congruence.

*Statistically significant at the 5 percent level. 


\section{Appendix: Detailed Estimation Results}

In this appendix I report the details of the estimation results. To organize the presentation, I focus on three questions: What are the consequences of a change in the search strategy given the estimation method? What are the effects of a change in the estimation method given the search strategy? Finally, what happens to the estimates in response to a change in lag-length given estimation method and search strategy?

\section{Aggregate Services}

Exports: The estimates suggest that aggregate service exports are income elastic and price inelastic (figure A1, top panel; table A1). However, differences in initial lag lengths, in estimation method, and in search strategies translate into different point estimates in most instances. For example, IV estimation using 8 lags and no search suggests that the income elasticity is zero whereas relying on automated search yields an income elasticity of 1.7 .

Imports: The estimates suggest that aggregate service imports are income elastic and price elastic (figure A1, bottom panel; table A2). The OLS estimates are not sensitive to changes in the number of lags and are, in general, unaffected by the adoption of an automated strategy. In contrast, the IV estimates are quite sensitive to lag length: general formulations with more than four lags yield positive price elasticities. 
Figure A1: Income and Price Elasticities for Aggregate Exports and Imports of Services - 1987-2001

Alternative Estimation Methods and Automated Specification Algorithms
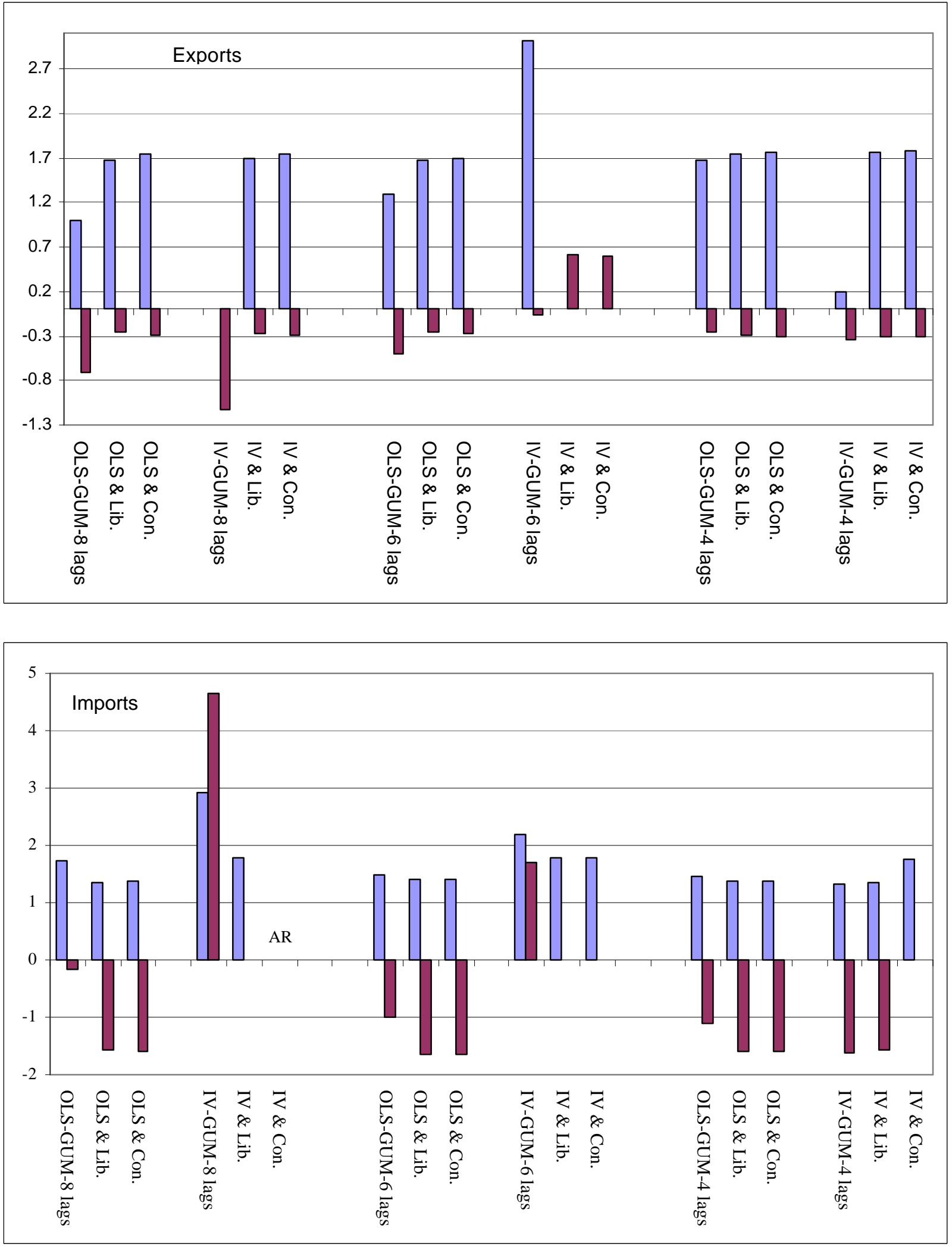

AR: Autoregressive Specification

GUM: General Unrestricted Model

Lib:. Liberal specification strategy

Con.: Conservative specification strategy 
Table A1: Long-run Income and Price Elasticities for Exports of Aggregate Services - 1987-2001 Alternative Estimation Methods and Automated Specification Algorithms

\begin{tabular}{|c|c|c|c|c|c|c|c|c|c|c|c|}
\hline Lags & Method & Income & $\begin{array}{l}\text { Own- } \\
\text { Price }\end{array}$ & $\mathrm{JB}$ & AR & $\mathrm{ARCH}$ & $\begin{array}{c}\text { SER- } \\
\text { GUM(\%) }\end{array}$ & $\begin{array}{c}\text { SER- } \\
\text { Spec }(\%)\end{array}$ & $\begin{array}{c}\text { Par- } \\
\text { GUM }\end{array}$ & $\begin{array}{l}\text { Par- } \\
\text { Spec }\end{array}$ & $\begin{array}{l}\text { Max Lag } \\
\text { in Spec }\end{array}$ \\
\hline \multirow[t]{6}{*}{8} & OLS \& GUM & 0.99 & -0.70 & $\mathrm{Y}$ & $\mathrm{Y}$ & $\mathrm{Y}$ & 1.50 & 1.50 & 28 & 28 & 8 \\
\hline & OLS \& Lib. Search & $1.67 *$ & $-0.26^{*}$ & $\mathrm{Y}$ & $\mathrm{Y}$ & $\mathrm{Y}$ & 1.50 & 1.32 & 28 & 7 & 6 \\
\hline & OLS \& Con. Search & $1.74 *$ & $-0.29 *$ & $\mathrm{Y}$ & $\mathrm{Y}$ & $\mathrm{Y}$ & 1.50 & 1.51 & 28 & 4 & 6 \\
\hline & IV \& GUM & 0.00 & -1.12 & $\mathrm{Y}$ & $\mathrm{Y}$ & $Y$ & 1.51 & 1.51 & 28 & 28 & 8 \\
\hline & IV \& Lib. Search & $1.69 *$ & $-0.27 *$ & $\mathrm{Y}$ & Y & $\mathrm{Y}$ & 1.51 & 1.37 & 28 & 5 & 6 \\
\hline & IV \& Con. Search & $1.74 *$ & $-0.29 *$ & $\mathrm{Y}$ & Y & $\mathrm{Y}$ & 1.51 & 1.50 & 28 & 4 & 6 \\
\hline \multirow[t]{6}{*}{6} & OLS \& GUM & $1.29 *$ & -0.50 & $\mathrm{Y}$ & Y & $\mathrm{Y}$ & 1.35 & 1.35 & 22 & 22 & 6 \\
\hline & OLS \& Lib. Search & $1.67 *$ & $-0.26^{*}$ & $\mathrm{Y}$ & $\mathrm{Y}$ & $\mathrm{Y}$ & 1.35 & 1.32 & 22 & 7 & 6 \\
\hline & OLS \& Con. Search & $1.69 *$ & $-0.27 *$ & $\mathrm{Y}$ & $\mathrm{Y}$ & $\mathrm{Y}$ & 1.35 & 1.38 & 22 & 5 & 6 \\
\hline & IV \& GUM & 3.01 & -0.06 & $\mathrm{Y}$ & $\mathrm{Y}$ & $\mathrm{Y}$ & 2.89 & 2.89 & 22 & 22 & 6 \\
\hline & IV \& Lib. Search & $0.00 \mathrm{e}$ & $+0.61 *$ & $\mathrm{Y}$ & $\mathrm{Y}$ & $\mathrm{Y}$ & 2.89 & 2.44 & 22 & 5 & 6 \\
\hline & IV \& Con. Search & $0.00 \mathrm{e}$ & $+0.59 *$ & $\mathrm{Y}$ & $\mathrm{Y}$ & $\mathrm{Y}$ & 2.89 & 2.46 & 22 & 4 & 1 \\
\hline \multirow[t]{6}{*}{4} & OLS \& GUM & $1.67 *$ & $-0.26^{*}$ & $\mathrm{Y}$ & Y & $\mathrm{Y}$ & 1.59 & 1.59 & 16 & 16 & 4 \\
\hline & OLS \& Lib. Search & $1.74 *$ & $-0.29 *$ & $\mathrm{Y}$ & $\mathrm{Y}$ & $\mathrm{Y}$ & 1.59 & 1.50 & 16 & 5 & 4 \\
\hline & OLS \& Con. Search & $1.76^{*}$ & $-0.30 *$ & $\mathrm{Y}$ & $\mathrm{Y}$ & $\mathrm{Y}$ & 1.59 & 1.53 & 16 & 4 & 4 \\
\hline & IV \& GUM & 0.20 & -0.34 & $\mathrm{Y}$ & $\mathrm{Y}$ & $\mathrm{Y}$ & 2.29 & 2.29 & 16 & 16 & 4 \\
\hline & IV \& Lib. Search & $1.76^{*}$ & $-0.30 *$ & $\mathrm{Y}$ & $\mathrm{Y}$ & $\mathrm{Y}$ & 2.29 & 1.59 & 16 & 4 & 3 \\
\hline & IV \& Con. Search & $1.77 *$ & $-0.30 *$ & $\mathrm{Y}$ & $\mathrm{Y}$ & $\mathrm{Y}$ & 2.29 & 1.69 & 16 & 4 & 1 \\
\hline
\end{tabular}

\begin{tabular}{lcccc}
\hline & \multicolumn{5}{c}{ FIML: Number of lags in the VAR } \\
\hline & 8 & 6 & 4 & 2 \\
Income Elasticity & $1.81^{*}$ & $3.14^{*}$ & $1.33^{*}$ & $1.67^{*}$ \\
Own-Price Elasticity & -0.17 & +0.56 & -0.37 & -0.23 \\
Loading Coefficient & -0.20 & +0.05 & -0.188 & $-0.28^{*}$ \\
& & & & \\
No. Cointegration vectors & 2 & 2 & 1 & 0 \\
JB & & & & \\
AR & $\mathrm{Y}$ & $\mathrm{Y}$ & $\mathrm{Y}$ & $\mathrm{Y}$ \\
$\mathrm{ARCH}$ & $\mathrm{Y}$ & $\mathrm{Y}$ & $\mathrm{Y}$ & $\mathrm{Y}$ \\
& $\mathrm{Na}$ & $\mathrm{Y}$ & $\mathrm{Y}$ & $\mathrm{Y}$ \\
\hline
\end{tabular}

*Statistically significant at the 5 percent level

JB: Jarque-Bera test for normality

AR: Test of Serial independence for the residuals

ARCH test of constant

GUM: General Unrestricted Model

SER-GUM: Standard error of the regression associated with the General Unrestricted Model

SER-Spec: Standard error of the regression associated with the Specific Model

Par-GUM: Number of parameters in the General Unrestricted Model

Par-Spec: Number of parameters estimated in the Specific Model

Max-Lag in Spec: Maximum lag-length in the Specific Model

Y: One cannot reject the associated null hypothesis

$\mathrm{N}$ : One cannot accept the associated null hypothesis

e: Automated specification excludes this variable

$\mathrm{Na}$ : Not Applicable because of insufficient degrees of freedom. 
Table A2: Long-run Income and Price Elasticities for Imports of Aggregate Services - 1987-2001

Alternative Estimation Methods and Automated Specification Algorithms

\begin{tabular}{|c|c|c|c|c|c|c|c|c|c|c|c|}
\hline Lags & Method & Income & $\begin{array}{l}\text { Own- } \\
\text { Price }\end{array}$ & JB & AR & $\mathrm{ARCH}$ & $\begin{array}{c}\text { SER- } \\
\text { GUM }(\%)\end{array}$ & $\begin{array}{l}\text { SER- } \\
\text { Spec } \\
(\%)\end{array}$ & $\begin{array}{l}\text { Par- } \\
\text { GUM }\end{array}$ & $\begin{array}{l}\text { Par- } \\
\text { Spec }\end{array}$ & $\begin{array}{l}\text { Max Lag } \\
\text { in Spec }\end{array}$ \\
\hline 8 & $\begin{array}{r}\text { OLS \& GUM } \\
\text { OLS \& Lib. Search } \\
\text { OLS \& Con. Search }\end{array}$ & $\begin{array}{l}1.72^{*} \\
1.36^{*} \\
1.37^{*}\end{array}$ & $\begin{array}{l}-0.15 \\
-1.58^{*} \\
-1.60^{*}\end{array}$ & $\begin{array}{l}\mathrm{Y} \\
\mathrm{Y} \\
\mathrm{Y}\end{array}$ & $\begin{array}{l}\mathrm{Y} \\
\mathrm{Y} \\
\mathrm{Y}\end{array}$ & $\begin{array}{l}\mathrm{Y} \\
\mathrm{Y} \\
\mathrm{Y}\end{array}$ & $\begin{array}{l}1.96 \\
1.96 \\
1.96\end{array}$ & $\begin{array}{l}1.96 \\
1.74 \\
1.75\end{array}$ & $\begin{array}{l}28 \\
28 \\
28\end{array}$ & $\begin{array}{c}28 \\
6 \\
5\end{array}$ & $\begin{array}{l}8 \\
6 \\
3\end{array}$ \\
\hline & $\begin{array}{r}\text { IV \& GUM } \\
\text { IV \& Lib. Search } \\
\text { IV \& Con. Search }\end{array}$ & $\begin{array}{l}2.92 \\
1.78^{*} \\
0.00 \mathrm{e}\end{array}$ & $\begin{array}{l}+4.64 \\
0.00 \mathrm{e} \\
0.00 \mathrm{e}\end{array}$ & $\begin{array}{l}\mathrm{Y} \\
\mathrm{Y} \\
\mathrm{Y}\end{array}$ & $\begin{array}{l}\mathrm{N} \\
\mathrm{N} \\
\mathrm{N}\end{array}$ & $\begin{array}{l}\mathrm{Y} \\
\mathrm{Y} \\
\mathrm{Y}\end{array}$ & $\begin{array}{l}2.50 \\
2.50 \\
2.50\end{array}$ & $\begin{array}{l}2.50 \\
1.90 \\
2.29\end{array}$ & $\begin{array}{l}28 \\
28 \\
28\end{array}$ & $\begin{array}{c}28 \\
6 \\
3\end{array}$ & $\begin{array}{l}8 \\
6 \\
1\end{array}$ \\
\hline 6 & $\begin{array}{r}\text { OLS \& GUM } \\
\text { OLS \& Lib. Search } \\
\text { OLS \& Con. Search }\end{array}$ & $\begin{array}{l}1.49^{*} \\
1.40^{*} \\
1.40^{*}\end{array}$ & $\begin{array}{l}-0.99 \\
-1.65^{*} \\
-1.65^{*}\end{array}$ & $\begin{array}{l}\mathrm{Y} \\
\mathrm{Y} \\
\mathrm{Y}\end{array}$ & $\begin{array}{l}\mathrm{N} \\
\mathrm{N} \\
\mathrm{Y}\end{array}$ & $\begin{array}{l}\mathrm{Y} \\
\mathrm{Y} \\
\mathrm{Y}\end{array}$ & $\begin{array}{l}1.83 \\
1.83 \\
1.83\end{array}$ & $\begin{array}{l}1.83 \\
1.79 \\
1.79\end{array}$ & $\begin{array}{l}22 \\
22 \\
22\end{array}$ & $\begin{array}{c}22 \\
5 \\
5\end{array}$ & $\begin{array}{l}6 \\
5 \\
5\end{array}$ \\
\hline & $\begin{array}{r}\text { IV \& GUM } \\
\text { IV \& Lib. Search } \\
\text { IV \& Con. Search }\end{array}$ & $\begin{array}{l}2.18 \\
1.78^{*} \\
1.78^{*}\end{array}$ & $\begin{array}{l}+1.71 \\
0.00 \mathrm{e} \\
0.00 \mathrm{e}\end{array}$ & $\begin{array}{l}\mathrm{Y} \\
\mathrm{Y} \\
\mathrm{Y}\end{array}$ & $\begin{array}{l}\mathrm{N} \\
\mathrm{N} \\
\mathrm{N}\end{array}$ & $\begin{array}{l}\mathrm{Y} \\
\mathrm{Y} \\
\mathrm{Y}\end{array}$ & $\begin{array}{l}2.72 \\
2.72 \\
2.72\end{array}$ & $\begin{array}{l}2.72 \\
1.90 \\
1.90\end{array}$ & $\begin{array}{l}22 \\
22 \\
22\end{array}$ & $\begin{array}{c}22 \\
6 \\
6\end{array}$ & $\begin{array}{l}6 \\
6 \\
6\end{array}$ \\
\hline 4 & $\begin{array}{r}\text { OLS \& GUM } \\
\text { OLS \& Lib. Search } \\
\text { OLS \& Con. Search }\end{array}$ & $\begin{array}{l}1.47^{*} \\
1.37^{*} \\
1.37^{*}\end{array}$ & $\begin{array}{l}-1.10^{*} \\
-1.60^{*} \\
-1.60^{*}\end{array}$ & $\begin{array}{l}\mathrm{Y} \\
\mathrm{N} \\
\mathrm{Y}\end{array}$ & $\begin{array}{l}\mathrm{Y} \\
\mathrm{Y} \\
\mathrm{Y}\end{array}$ & $\begin{array}{l}\mathrm{Y} \\
\mathrm{Y} \\
\mathrm{Y}\end{array}$ & $\begin{array}{l}1.75 \\
1.75 \\
1.75\end{array}$ & $\begin{array}{l}1.75 \\
1.68 \\
1.75\end{array}$ & $\begin{array}{l}16 \\
16 \\
16\end{array}$ & $\begin{array}{c}16 \\
9 \\
5\end{array}$ & $\begin{array}{l}4 \\
4 \\
3\end{array}$ \\
\hline & $\begin{array}{r}\text { IV \& GUM } \\
\text { IV \& Lib. Search } \\
\text { IV \& Con. Search }\end{array}$ & $\begin{array}{l}1.32^{*} \\
1.36^{*} \\
1.76^{*}\end{array}$ & $\begin{array}{c}-1.62 \\
-1.57 * \\
0.00 \mathrm{e}\end{array}$ & $\begin{array}{l}\mathrm{Y} \\
\mathrm{Y} \\
\mathrm{Y}\end{array}$ & $\begin{array}{l}\mathrm{Y} \\
\mathrm{Y} \\
\mathrm{Y}\end{array}$ & $\begin{array}{l}\mathrm{Y} \\
\mathrm{Y} \\
\mathrm{Y}\end{array}$ & $\begin{array}{l}1.77 \\
1.77 \\
1.77\end{array}$ & $\begin{array}{l}1.77 \\
1.66 \\
1.84\end{array}$ & $\begin{array}{l}16 \\
16 \\
16\end{array}$ & $\begin{array}{c}16 \\
8 \\
6\end{array}$ & $\begin{array}{l}4 \\
4 \\
3\end{array}$ \\
\hline
\end{tabular}

\begin{tabular}{lcccc}
\hline & \multicolumn{5}{c}{ FIML: Number of lags in the VAR } \\
\hline & 8 & 6 & 4 & 2 \\
Income Elasticity & $3.14^{*}$ & $3.47^{*}$ & $2.07^{*}$ & $1.55^{*}$ \\
Own-Price Elasticity & $+5.25^{*}$ & $+6.96^{*}$ & +1.23 & $-0.92^{*}$ \\
Loading Coefficient & $-0.22^{*}$ & $-0.13^{*}$ & $-0.35^{*}$ & $-0.27^{*}$ \\
& & & & \\
No. Cointegration vectors & 0 & 0 & 1 & 1 \\
JB & & & & \\
AR & $\mathrm{Y}$ & $\mathrm{Y}$ & $\mathrm{Y}$ & $\mathrm{Y}$ \\
ARCH & $\mathrm{Y}$ & $\mathrm{Y}$ & $\mathrm{Y}$ & $\mathrm{N}$ \\
\hline
\end{tabular}

*Statistically significant at the 5 percent level

JB: Jarque-Bera test of null hypothesis of normality in the residuals

AR: Test of null hypothesis of serial independence for the residuals

ARCH: Test of null hypothesis of constant variance of the residuals

GUM: General Unrestricted Model

SER-GUM: Standard error of the regression associated with the General Unrestricted Model

SER-Spec: Standard error of the regression associated with the Specific Model

Par-GUM: Number of parameters in the General Unrestricted Model

Par-Spec: Number of parameters estimated in the Specific Model

Max-Lag in Spec: Maximum lag-length in the Specific Model

Y: One cannot reject the associated null hypothesis

$\mathrm{N}$ : One cannot accept the associated null hypothesis

e: Automated specification excludes this variable

Na: Not Applicable because of insufficient degrees of freedom. 


\section{Other Private}

Exports: Automated search matters in every instance except OLS with eight lags (figure A2, top panel; table A3). Specifically, the only instances of negative price elasticities involve combining instrumental variables and automated search: without these two features, the results do not support the conventional imperfect substitute model. Finally, the choice of search strategy matters a lot. Specifically, there are three instances in which the best-fitting model is an autoregressive formulation; each of these instances stems from relying on a conservative search strategy.

Imports: Automated search matters for every configuration of estimation method and lag length; the choice of automated specification strategy is less relevant (figure A2 bottom; table A4). For example, the IV estimate of the price elasticity with 8 lags and no search is positive whereas reliance on automated search yields a negative price elasticity. Simultaneity also matters: price elasticities based on OLS are much smaller (in absolute value) than the corresponding IV estimates. 
Figure A2: Long-run Income and Price Elasticities for Exports and Imports of Other Private Services - 1987-2001

Alternative Estimation Methods and Automated Specification Algorithms
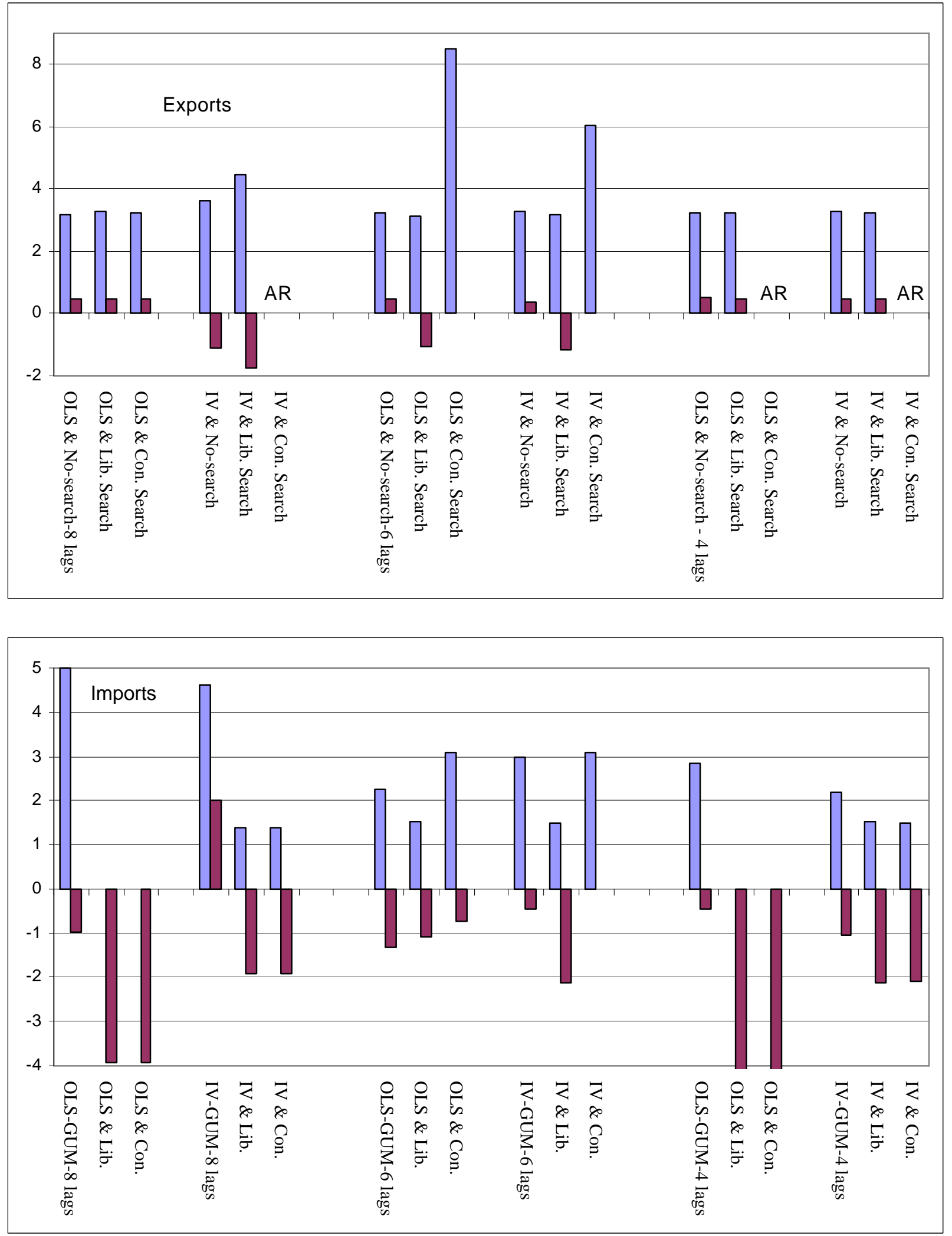

AR: Autoregressive Specification

GUM: General Unrestricted Model

Lib.: Liberal specification strategy

Con.: Conservative specification strategy 
Table A3: Long-run Income and Price Elasticities for Exports of Other Private Services - 1987-2001

Alternative Estimation Methods and Automated Specification Algorithms

\begin{tabular}{|c|c|c|c|c|c|c|c|c|c|c|c|}
\hline Lags & Method & Income & $\begin{array}{l}\text { Own- } \\
\text { Price }\end{array}$ & JB & $\overline{\mathrm{AR}}$ & $\mathrm{ARCH}$ & $\begin{array}{c}\text { SER- } \\
\text { GUM( } \%)\end{array}$ & $\begin{array}{l}\text { SER- } \\
\text { Spec } \\
(\%)\end{array}$ & $\begin{array}{l}\text { Par- } \\
\text { GUM }\end{array}$ & $\begin{array}{l}\text { Par- } \\
\text { Spec }\end{array}$ & $\begin{array}{l}\text { Max Lag } \\
\text { in Spec }\end{array}$ \\
\hline \multirow[t]{6}{*}{8} & OLS \& GUM & $3.18 *$ & +0.49 & $\mathrm{Y}$ & $\mathrm{Y}$ & $\mathrm{Y}$ & 1.76 & 1.76 & 27 & 27 & 8 \\
\hline & OLS \& Lib. Search & $3.28 *$ & $+0.47 *$ & $\mathrm{Y}$ & Y & $\mathrm{Y}$ & 1.76 & 1.54 & 27 & 10 & 6 \\
\hline & OLS \& Con. Search & $3.25^{*}$ & $+0.46^{*}$ & $\mathrm{Y}$ & $\mathrm{Y}$ & $\mathrm{Y}$ & 1.76 & 1.78 & 27 & 5 & 5 \\
\hline & IV \& GUM & 3.60 & -1.12 & $\mathrm{Y}$ & $\mathrm{Y}$ & $\mathrm{Y}$ & 2.37 & 2.37 & 27 & 27 & 8 \\
\hline & IV \& Lib. Search & 4.48 & -1.73 & $\mathrm{Y}$ & Y & $\mathrm{Y}$ & 2.37 & 1.87 & 27 & 9 & 7 \\
\hline & IV \& Con. Search & $0.00 \mathrm{e}$ & $0.00 \mathrm{e}$ & $\mathrm{Y}$ & $\mathrm{Y}$ & $\mathrm{Y}$ & 2.37 & 1.98 & 27 & 1 & 1 \\
\hline \multirow[t]{6}{*}{6} & OLS \& GUM & $3.23^{*}$ & +0.48 & $\mathrm{Y}$ & $\mathrm{Y}$ & $\mathrm{Y}$ & 1.64 & 1.64 & 21 & 21 & 6 \\
\hline & OLS \& Lib. Search & $3.12 *$ & $-1.08 *$ & $\mathrm{Y}$ & $\mathrm{Y}$ & $\mathrm{Y}$ & 1.64 & 1.47 & 21 & 11 & 6 \\
\hline & OLS \& Con. Search & 8.50 & $0.00 \mathrm{e}$ & $\mathrm{Y}$ & $\mathrm{Y}$ & $\mathrm{Y}$ & 1.64 & 1.69 & 21 & 6 & 5 \\
\hline & IV \& GUM & $3.26^{*}$ & +0.35 & $\mathrm{Y}$ & $\mathrm{Y}$ & $\mathrm{Y}$ & 1.86 & 1.86 & 21 & 21 & 6 \\
\hline & IV \& Lib. Search & $3.20 *$ & $-1.14 *$ & $\mathrm{Y}$ & $\mathrm{Y}$ & $\mathrm{Y}$ & 1.86 & 1.53 & 21 & 11 & 6 \\
\hline & IV \& Con. Search & 6.03 & $0.00 \mathrm{e}$ & $\mathrm{Y}$ & $\mathrm{Y}$ & $\mathrm{Y}$ & 1.86 & 1.69 & 21 & 6 & 5 \\
\hline \multirow[t]{6}{*}{4} & OLS \& GUM & $3.23^{*}$ & $+0.54 *$ & $\mathrm{Y}$ & $\mathrm{Y}$ & $\mathrm{Y}$ & 1.84 & 1.84 & 15 & 15 & 4 \\
\hline & OLS \& Lib. Search & $3.25^{*}$ & $+0.48^{*}$ & $\mathrm{Y}$ & $\mathrm{Y}$ & $\mathrm{Y}$ & 1.84 & 1.74 & 15 & 7 & 4 \\
\hline & OLS \& Con. Search & $0.00 \mathrm{e}$ & $0.00 \mathrm{e}$ & $\mathrm{Y}$ & $\mathrm{Y}$ & $\mathrm{Y}$ & 1.84 & 1.98 & 15 & 1 & 1 \\
\hline & IV \& GUM & $3.27 *$ & $+0.49 *$ & $\mathrm{Y}$ & $\mathrm{Y}$ & $\mathrm{Y}$ & 2.32 & 2.32 & 15 & 15 & 4 \\
\hline & IV \& Lib. Search & $3.22 *$ & $+0.48^{*}$ & $\mathrm{Y}$ & $\mathrm{Y}$ & $\mathrm{Y}$ & 2.32 & 1.93 & 15 & 5 & 1 \\
\hline & IV \& Con. Search & $0.00 \mathrm{e}$ & $0.00 \mathrm{e}$ & $\mathrm{Y}$ & $\mathrm{Y}$ & $\mathrm{Y}$ & 2.32 & 1.98 & 15 & 1 & 1 \\
\hline
\end{tabular}

\begin{tabular}{lcccc}
\hline & \multicolumn{4}{c}{ FIML: lags in the VAR } \\
\hline & 8 & 6 & 4 & 2 \\
Income Elasticity & $4.09^{*}$ & $3.79^{*}$ & $2.57^{*}$ & 0.68 \\
Own-Price Elasticity & -1.72 & $-1.52^{*}$ & $-0.75^{*}$ & +0.35 \\
Loading Coefficient & 0.01 & 0.01 & $-0.03^{*}$ & 0.00 \\
No. Cointegration vectors & 2 & 1 & 0 & 0 \\
JB & & & & \\
AR & $\mathrm{Y}$ & $\mathrm{Y}$ & $\mathrm{Y}$ & $\mathrm{Y}$ \\
ARCH & $\mathrm{Y}$ & $\mathrm{Y}$ & $\mathrm{Y}$ & $\mathrm{Y}$ \\
\hline
\end{tabular}

*Statistically significant at the 5 percent level

JB: Jarque-Bera test of null hypothesis of normality in the residuals

AR: Test of null hypothesis of serial independence for the residuals

ARCH: Test of null hypothesis of constant variance of the residuals

GUM: General Unrestricted Model

SER-GUM: Standard error of the regression associated with the General Unrestricted Model

SER-Spec: Standard error of the regression associated with the Specific Model

Par-GUM: Number of parameters in the General Unrestricted Model

Par-Spec: Number of parameters estimated in the Specific Model

Max-Lag in Spec: Maximum lag-length in the Specific Model

Y: One cannot reject the associated null hypothesis

$\mathrm{N}$ : One cannot accept the associated null hypothesis

e: Automated specification excludes this variable

Na: Not Applicable because of insufficient degrees of freedom. 
Table A4: Long-run Income and Price Elasticities for Imports of Other Private Services - 1987-2001

Alternative Estimation Methods and Automated Specification Algorithms

\begin{tabular}{|c|c|c|c|c|c|c|c|c|c|c|}
\hline Lags & Method & Income & $\begin{array}{l}\text { Own- } \\
\text { Price }\end{array}$ & $\mathrm{JB}$ & AR & $\mathrm{ARCH}$ & $\begin{array}{c}\text { SER- } \\
\text { GUM(\%) }\end{array}$ & $\begin{array}{l}\text { SER- } \\
\text { Spec } \\
(\%)\end{array}$ & $\begin{array}{l}\text { Par- } \\
\text { GUM }\end{array}$ & $\begin{array}{l}\text { Par } \\
\text { Spe }\end{array}$ \\
\hline \multirow[t]{6}{*}{8} & OLS \& GUM & $5.00 *$ & -0.97 & $\mathrm{Y}$ & $\mathrm{Y}$ & $\mathrm{Y}$ & 4.89 & 4.89 & 28 & \\
\hline & OLS \& Lib. Search & $0.00 \mathrm{e}$ & $-3.94 *$ & $\mathrm{Y}$ & $\mathrm{Y}$ & $\mathrm{Y}$ & 4.89 & 4.26 & 28 & 7 \\
\hline & OLS \& Con. Search & $0.00 \mathrm{e}$ & $-3.94 *$ & $\mathrm{~N}$ & $\mathrm{~N}$ & Y & 4.89 & 4.26 & 28 & 7 \\
\hline & IV \& GUM & $4.63 *$ & +2.01 & $\mathrm{Y}$ & $\mathrm{Y}$ & $\mathrm{Y}$ & 5.15 & 5.15 & 28 & \\
\hline & IV \& Lib. Search & $1.39 *$ & $-1.91 *$ & $\mathrm{Y}$ & $\mathrm{Y}$ & $\mathrm{Y}$ & 5.15 & 4.10 & 28 & \\
\hline & IV \& Con. Search & $1.39 *$ & $-1.91 *$ & $\mathrm{Y}$ & Y & $\mathrm{Y}$ & 5.15 & 4.10 & 28 & I \\
\hline \multirow[t]{6}{*}{6} & OLS \& GUM & 2.26 & -1.31 & $\mathrm{Y}$ & $\mathrm{Y}$ & Y & 4.79 & 4.79 & 22 & \\
\hline & OLS \& Lib. Search & $1.54 *$ & $-2.18 *$ & Y & $\mathrm{Y}$ & $\mathrm{Y}$ & 4.79 & 4.10 & 22 & \\
\hline & OLS \& Con. Search & $3.10^{*}$ & $0.00 \mathrm{e}$ & $\mathrm{N}$ & $\mathrm{Y}$ & $\mathrm{Y}$ & 4.79 & 4.32 & 22 & 4 \\
\hline & IV \& GUM & 2.97 & -0.46 & Y & $\mathrm{Y}$ & $\mathrm{Y}$ & 4.86 & 4.86 & 22 & \\
\hline & IV \& Lib. Search & $1.50^{*}$ & $-2.11 *$ & $\mathrm{Y}$ & $\mathrm{Y}$ & $\mathrm{Y}$ & 4.86 & 4.30 & 22 & \\
\hline & IV \& Con. Search & 3.10 & $0.00 \mathrm{e}$ & Y & Y & Y & 4.86 & 4.32 & 22 & 4 \\
\hline \multirow[t]{15}{*}{4} & OLS \& GUM & $2.86^{*}$ & -0.47 & Y & $\mathrm{Y}$ & Y & 4.44 & 4.44 & 16 & \\
\hline & OLS \& Lib. Search & $0.00 \mathrm{e}$ & $-4.12 *$ & $\mathrm{Y}$ & $\mathrm{N}$ & $\mathrm{Y}$ & 4.44 & 4.22 & 16 & \\
\hline & OLS \& Con. Search & $0.00 \mathrm{e}$ & $-4.12 *$ & Y & $\mathrm{N}$ & $\mathrm{Y}$ & 4.44 & 4.22 & 16 & \\
\hline & IV \& GUM & 2.18 & -1.06 & $\mathrm{Y}$ & $\mathrm{Y}$ & $\mathrm{Y}$ & 5.13 & 5.13 & 16 & 6 \\
\hline & IV \& Lib. Search & $1.52 *$ & $-2.14 *$ & $\mathrm{Y}$ & $\mathrm{Y}$ & $\mathrm{Y}$ & 5.13 & 4.07 & 16 & \\
\hline & IV \& Con. Search & $1.49^{*}$ & $-2.10^{*}$ & $\mathrm{Y}$ & $\mathrm{Y}$ & $\mathrm{Y}$ & 5.13 & 4.30 & 16 & 4 \\
\hline & & & \multicolumn{8}{|c|}{ FIML: Number of Lags in VAR } \\
\hline & & & & 8 & 6 & & 4 & 3 & 2 & \\
\hline & \multirow{3}{*}{\multicolumn{2}{|c|}{$\begin{array}{l}\text { Income Elasticity } \\
\text { Own-Price Elasticity } \\
\text { Loading Coefficient }\end{array}$}} & \multicolumn{2}{|r|}{1.09} & \multicolumn{2}{|l|}{0.66} & $1.73^{*}$ & $1.70^{*}$ & \multicolumn{2}{|l|}{$1.74 *$} \\
\hline & & & & -1.56 & -0.74 & & $-2.51 *$ & $-2.45^{*}$ & $-2.51 *$ & \\
\hline & & & & 0.03 & 0.03 & & -0.18 & $-0.20 *$ & $-0.12 *$ & \\
\hline & \multicolumn{2}{|c|}{ No. Cointegration vectors } & \multicolumn{2}{|r|}{0} & \multicolumn{2}{|l|}{2} & 2 & 1 & 2 & \\
\hline & \multicolumn{2}{|l|}{ JB } & \multicolumn{2}{|r|}{$\mathrm{N}$} & \multicolumn{2}{|l|}{$\mathrm{N}$} & $\mathrm{N}$ & $\mathrm{N}$ & $\mathrm{N}$ & \\
\hline & \multirow{2}{*}{\multicolumn{2}{|c|}{$\begin{array}{l}\text { AR } \\
\text { ARCH }\end{array}$}} & \multirow{2}{*}{\multicolumn{2}{|c|}{$\mathrm{Na}$}} & \multirow{2}{*}{\multicolumn{2}{|c|}{$\begin{array}{l}\text { Y } \\
Y\end{array}$}} & $\mathrm{Y}$ & $\mathrm{Y}$ & $\mathrm{Y}$ & \\
\hline & & & & & & & $\mathrm{Y}$ & $\mathrm{Y}$ & $\mathrm{Y}$ & \\
\hline
\end{tabular}

*Statistically significant at the 5 percent level

JB: Jarque-Bera test of null hypothesis of normality in the residuals

AR: Test of null hypothesis of serial independence for the residuals

ARCH: Test of null hypothesis of constant variance of the residuals

GUM: General Unrestricted Model

SER-GUM: Standard error of the regression associated with the General Unrestricted Model

SER-Spec: Standard error of the regression associated with the Specific Model

Par-GUM: Number of parameters in the General Unrestricted Model

Par-Spec: Number of parameters estimated in the Specific Model

Max-Lag in Spec: Maximum lag-length in the Specific Model

Y: One cannot reject the associated null hypothesis

$\mathrm{N}$ : One cannot accept the associated null hypothesis

e: Automated specification excludes this variable

Na: Not Applicable because of insufficient degrees of freedom. 


\section{Fares}

Exports: Changes in lag lengths, estimation methods, and automated specification strategies do not yield elasticity estimates helpful to predicting external imbalances in terms of movements in income and relative prices (figure A3 top; table A5). Specifically, for one-third of the final specifications, automated search algorithms suggest that the best model for export fares is an autoregressive formulation. The sole exception to this pattern is the specification using 8 lags with no search. For this case, the income elasticity is a little less than a half and the price elasticity is about minus one.

Imports: For specifications using less than eight lags, the estimated income and price elasticities show a narrow range of variation across estimation methods and search strategies: simultaneity biases are small and reliance on automated search makes little difference for inference (figure A3 bottom; table A6). For eight lags, however, changes in either the choice of strategy or the estimation method have large effects on the point estimates. 
Figure A3: Long-run Income and Price Elasticities for Aggregate Exports and Imports of Fare Services - 1987-2001 Alternative Estimation Methods and Automated Specification Algorithms
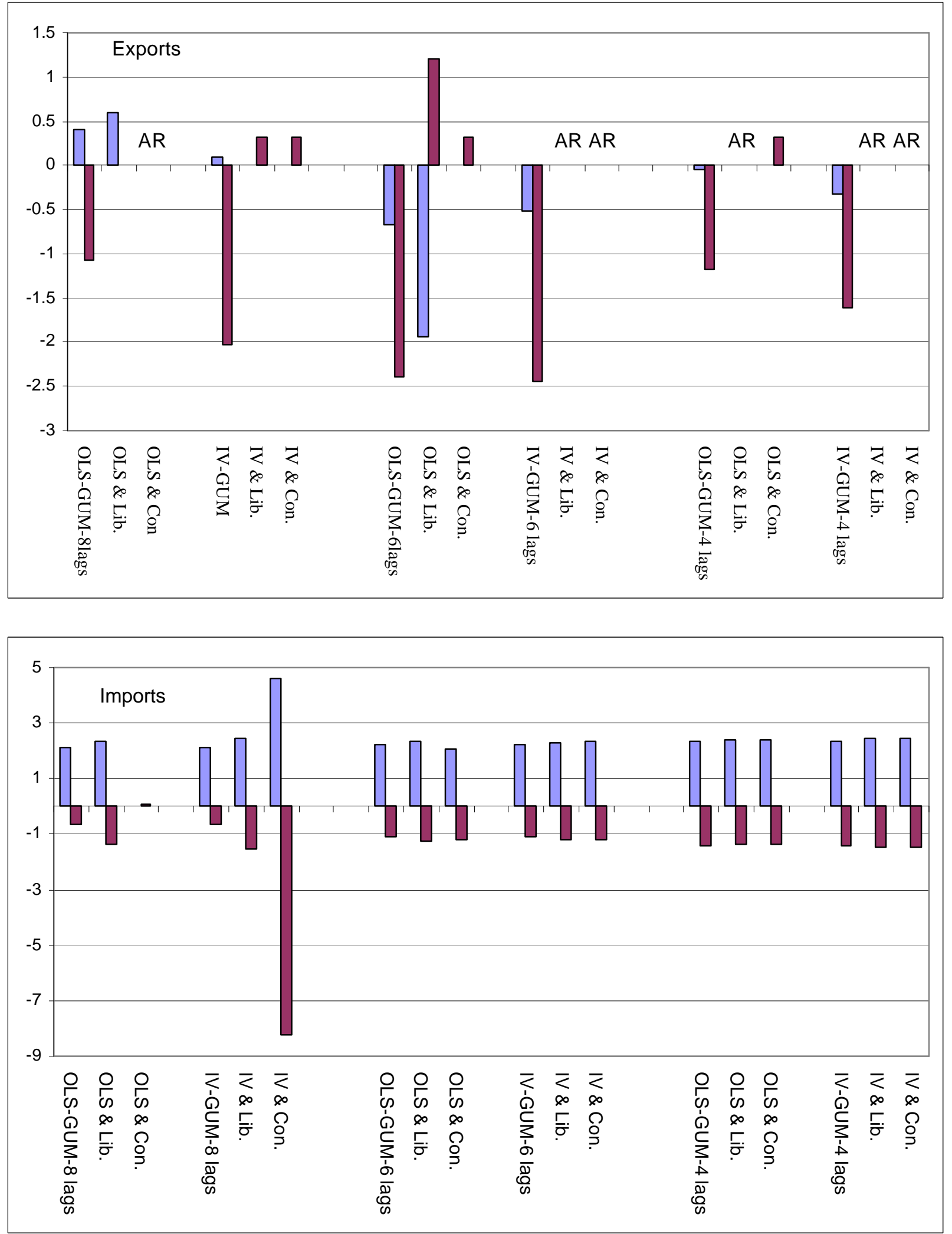

AR: Autoregressive Specification

GUM: General Unrestricted Model

Lib.: Liberal specification strategy

Con.: Conservative specification strategy 
Table A5: Long-run Income and Price Elasticities for Exports of Fares - 1987-2001

Alternative Estimation Methods and Automated Specification Algorithms

\begin{tabular}{|c|c|c|c|c|c|c|c|c|c|c|c|}
\hline lags & Method & Income & $\begin{array}{l}\text { Own- } \\
\text { Price }\end{array}$ & JB & AR & $\mathrm{ARCH}$ & $\begin{array}{c}\text { SER- } \\
\text { GUM(\%) }\end{array}$ & $\begin{array}{c}\text { SER- } \\
\text { Spec }(\%)\end{array}$ & $\begin{array}{c}\text { Par- } \\
\text { GUM } \\
\end{array}$ & $\begin{array}{l}\text { Par- } \\
\text { Spec }\end{array}$ & $\begin{array}{l}\text { Max Lag } \\
\text { in Spec }\end{array}$ \\
\hline \multirow[t]{6}{*}{8} & OLS \& GUM & 0.40 & -1.07 & $\mathrm{Y}$ & $\mathrm{Y}$ & $\mathrm{Y}$ & 5.31 & 5.31 & 28 & 28 & 8 \\
\hline & OLS \& Lib. Search & 0.59 & 0.01 & $\mathrm{Y}$ & Y & $\mathrm{Y}$ & 5.31 & 4.47 & 28 & 9 & 8 \\
\hline & OLS \& Con. Search & $0.00 \mathrm{e}$ & $0.00 \mathrm{e}$ & $\mathrm{Y}$ & $\mathrm{Y}$ & $\mathrm{Y}$ & 5.31 & 5.07 & 28 & 3 & 1 \\
\hline & IV \& GUM & 0.10 & $-2.02 *$ & $\mathrm{Y}$ & $\mathrm{Y}$ & $\mathrm{Y}$ & 7.85 & 7.85 & 28 & 28 & 8 \\
\hline & IV \& Lib. Search & $0.00 \mathrm{e}$ & $0.32 *$ & $\mathrm{Y}$ & $\mathrm{Y}$ & $\mathrm{Y}$ & 7.85 & 7.10 & 28 & 3 & 6 \\
\hline & IV \& Con. Search & $0.00 \mathrm{e}$ & $0.32 *$ & $\mathrm{Y}$ & $\mathrm{Y}$ & $\mathrm{Y}$ & 7.85 & 5.10 & 28 & 3 & 6 \\
\hline \multirow[t]{6}{*}{6} & OLS \& GUM & -0.68 & -2.39 & $\mathrm{Y}$ & $\mathrm{Y}$ & $\mathrm{Y}$ & 4.98 & 4.98 & 22 & 22 & 6 \\
\hline & OLS \& Lib. Search & -1.94 & 1.2 & $\mathrm{Y}$ & $\mathrm{Y}$ & $\mathrm{N}$ & 4.98 & 4.81 & 22 & 7 & 6 \\
\hline & OLS \& Con. Search & $0.00 \mathrm{e}$ & $+0.32 *$ & $\mathrm{Y}$ & $\mathrm{Y}$ & $\mathrm{Y}$ & 4.98 & 5.14 & 22 & 3 & 5 \\
\hline & IV \& GUM & -0.51 & -2.45 & $\mathrm{~N}$ & $\mathrm{Y}$ & $\mathrm{Y}$ & 6.10 & 6.10 & 22 & 22 & 6 \\
\hline & IV \& Lib. Search & $0.00 \mathrm{e}$ & $0.00 \mathrm{e}$ & $\mathrm{N}$ & $\mathrm{Y}$ & $\mathrm{Y}$ & 6.10 & 4.95 & 22 & 4 & 2 \\
\hline & IV \& Con. Search & $0.00 \mathrm{e}$ & $0.00 \mathrm{e}$ & $\mathrm{N}$ & $\mathrm{Y}$ & $\mathrm{Y}$ & 6.10 & 5.14 & 22 & 3 & 1 \\
\hline \multirow[t]{6}{*}{4} & OLS \& GUM & -0.04 & -1.18 & $\mathrm{Y}$ & $\mathrm{Y}$ & $\mathrm{Y}$ & 5.12 & 5.12 & 16 & 16 & 4 \\
\hline & OLS \& Lib. Search & $0.00 \mathrm{e}$ & $0.00 \mathrm{e}$ & $\mathrm{Y}$ & $\mathrm{Y}$ & $\mathrm{Y}$ & 5.12 & 4.95 & 16 & 4 & 2 \\
\hline & OLS \& Con. Search & $0.00 \mathrm{e}$ & $+0.32 *$ & $\mathrm{Y}$ & $\mathrm{Y}$ & $\mathrm{Y}$ & 5.12 & 5.14 & 16 & 3 & 1 \\
\hline & IV \& GUM & -0.33 & -1.61 & $\mathrm{~N}$ & $\mathrm{Y}$ & $\mathrm{Y}$ & 6.16 & 6.16 & 16 & 16 & 4 \\
\hline & IV \& Lib. Search & $0.00 \mathrm{e}$ & $0.00 \mathrm{e}$ & $\mathrm{N}$ & $\mathrm{Y}$ & $\mathrm{Y}$ & 6.16 & 4.95 & 16 & 4 & 2 \\
\hline & IV \& Con. Search & $0.00 \mathrm{e}$ & $0.00 \mathrm{e}$ & $\mathrm{N}$ & $\mathrm{Y}$ & $\mathrm{Y}$ & 6.16 & 5.07 & 16 & 3 & 1 \\
\hline
\end{tabular}

\begin{tabular}{lcccc}
\hline & \multicolumn{4}{c}{ FIML: Number of lags in the VAR } \\
\hline & 8 & 6 & 4 & 2 \\
Income Elasticity & 0.51 & $1.11^{*}$ & 2.76 & 1.88 \\
Own-Price Elasticity & $-2.10^{*}$ & $-1.43^{*}$ & $-2.03^{*}$ & $-2.29^{*}$ \\
Loading Coefficient & -0.09 & 0.01 & 0.10 & 0.04 \\
& & & & \\
No. Cointegration vectors & 1 & 1 & 0 & 0 \\
JB & & & & \\
AR & $\mathrm{Y}$ & $\mathrm{Y}$ & $\mathrm{N}$ & $\mathrm{N}$ \\
ARCH & $\mathrm{Y}$ & $\mathrm{Y}$ & $\mathrm{Y}$ & $\mathrm{Y}$ \\
\hline
\end{tabular}

*Statistically significant at the 5 percent level

JB: Jarque-Bera test of null hypothesis of normality in the residuals

AR: Test of null hypothesis of serial independence for the residuals

ARCH: Test of null hypothesis of constant variance of the residuals

GUM: General Unrestricted Model

SER-GUM: Standard error of the regression associated with the General Unrestricted Model

SER-Spec: Standard error of the regression associated with the Specific Model

Par-GUM: Number of parameters in the General Unrestricted Model

Par-Spec: Number of parameters estimated in the Specific Model

Max-Lag in Spec: Maximum lag-length in the Specific Model

Y: One cannot reject the associated null hypothesis

$\mathrm{N}$ : One cannot accept the associated null hypothesis

e: Automated specification excludes this variable

Na: Not Applicable because of insufficient degrees of freedom. 
Table A6: Long-run Income and Price Elasticities for Imports of Fares - 1987-2001

Alternative Estimation Methods and Automated Specification Algorithms

\begin{tabular}{|c|c|c|c|c|c|c|c|c|c|c|c|}
\hline Lags & Method & Income & $\begin{array}{l}\text { Own- } \\
\text { Price }\end{array}$ & JB & AR & $\mathrm{ARCH}$ & $\begin{array}{c}\text { SER- } \\
\text { GUM(\%) }\end{array}$ & $\begin{array}{l}\text { SER- } \\
\text { Spec } \\
(\%)\end{array}$ & $\begin{array}{l}\text { Par- } \\
\text { GUM }\end{array}$ & $\begin{array}{l}\text { Par- } \\
\text { Spec }\end{array}$ & $\begin{array}{l}\text { Max Lag } \\
\text { in Spec }\end{array}$ \\
\hline \multirow[t]{6}{*}{8} & OLS \& GUM & $2.12 *$ & $-0.62 *$ & $\mathrm{Y}$ & $\mathrm{Y}$ & $\mathrm{Y}$ & 3.46 & 3.46 & 29 & 29 & 8 \\
\hline & OLS \& Lib. Search & $2.36^{*}$ & $-1.37 *$ & $\mathrm{Y}$ & $\mathrm{Y}$ & $\mathrm{Y}$ & 3.46 & 3.00 & 29 & 9 & 7 \\
\hline & OLS \& Con. Search & $0.00 \mathrm{e}$ & 0.05 & $\mathrm{Y}$ & $\mathrm{Y}$ & Y & 3.46 & 3.30 & 29 & 7 & 7 \\
\hline & IV \& GUM & $2.12 *$ & -0.62 & $\mathrm{Y}$ & $\mathrm{Y}$ & $\mathrm{Y}$ & 3.46 & 3.46 & 29 & 29 & 8 \\
\hline & IV \& Lib. Search & $2.47 *$ & $-1.53 *$ & $\mathrm{Y}$ & $\mathrm{Y}$ & $\mathrm{Y}$ & 3.46 & 2.99 & 29 & 10 & 7 \\
\hline & IV \& Con. Search & $4.59 *$ & $-8.22 *$ & $\mathrm{Y}$ & $\mathrm{Y}$ & $\mathrm{Y}$ & 3.46 & 3.53 & 29 & 5 & 5 \\
\hline \multirow[t]{6}{*}{6} & OLS \& GUM & $2.23 *$ & $-1.06 *$ & $\mathrm{Y}$ & $\mathrm{Y}$ & $\mathrm{Y}$ & 3.41 & 3.41 & 23 & 23 & 6 \\
\hline & OLS \& Lib. Search & $2.36^{*}$ & $-1.28 *$ & $\mathrm{Y}$ & $\mathrm{Y}$ & $\mathrm{Y}$ & 3.41 & 3.18 & 23 & 8 & 5 \\
\hline & OLS \& Con. Search & $2.08^{*}$ & $-1.20 *$ & $\mathrm{Y}$ & $\mathrm{Y}$ & Y & 3.41 & 3.49 & 23 & 6 & 6 \\
\hline & IV \& GUM & $2.23 *$ & $-1.06 *$ & Y & Y & Y & 3.41 & 3.41 & 23 & 23 & 6 \\
\hline & IV \& Lib. Search & $2.29 *$ & $-1.22 *$ & $\mathrm{Y}$ & $\mathrm{Y}$ & $\mathrm{Y}$ & 3.41 & 3.10 & 23 & 10 & 6 \\
\hline & IV \& Con. Search & $2.33 *$ & $-1.22 *$ & $\mathrm{Y}$ & $\mathrm{Y}$ & $\mathrm{Y}$ & 3.41 & 3.94 & 23 & 4 & 1 \\
\hline \multirow[t]{6}{*}{4} & OLS \& GUM & $2.37 *$ & $-1.43 *$ & $\mathrm{Y}$ & $\mathrm{Y}$ & $\mathrm{Y}$ & 3.39 & 3.39 & 17 & 17 & 4 \\
\hline & OLS \& Lib. Search & $2.38^{*}$ & $-1.38 *$ & $\mathrm{Y}$ & $\mathrm{Y}$ & $\mathrm{Y}$ & 3.39 & 3.19 & 17 & 7 & 4 \\
\hline & OLS \& Con. Search & $2.38 *$ & $-1.38 *$ & $\mathrm{Y}$ & $\mathrm{Y}$ & $\mathrm{Y}$ & 3.39 & 3.19 & 17 & 7 & 4 \\
\hline & IV \& GUM & $2.37 *$ & $-1.43 *$ & Y & $\mathrm{Y}$ & $\mathrm{N}$ & 3.39 & 3.39 & 17 & 17 & 4 \\
\hline & IV \& Lib. Search & $2.46^{*}$ & $-1.49 *$ & $\mathrm{Y}$ & $\mathrm{Y}$ & $\mathrm{Y}$ & 3.39 & 3.21 & 17 & 8 & 4 \\
\hline & IV \& Con. Search & $2.45^{*}$ & $-1.49 *$ & Y & $\mathrm{Y}$ & $\mathrm{Y}$ & 3.39 & 3.21 & 17 & 8 & 4 \\
\hline
\end{tabular}

\begin{tabular}{lcccc}
\hline & \multicolumn{4}{c}{ FIML: Number of lags in the VAR } \\
\hline & 8 & 6 & 4 & 2 \\
Income Elasticity & $0.93^{*}$ & $2.11^{*}$ & $2.93^{*}$ & -0.12 \\
Own-Price Elasticity & +1.10 & $-0.92^{*}$ & $-2.45^{*}$ & $+3.31^{*}$ \\
Loading Coefficient & 0.09 & $-0.28^{*}$ & $-0.28^{*}$ & 0.02 \\
No. Cointegration vectors & 2 & 1 & 2 & 2 \\
JB & & & & \\
AR & $\mathrm{Y}$ & $\mathrm{Y}$ & $\mathrm{Y}$ & $\mathrm{Y}$ \\
ARCH & $\mathrm{Y}$ & $\mathrm{N}$ & $\mathrm{Y}$ & $\mathrm{Y}$ \\
\hline
\end{tabular}

*Statistically significant at the 5 percent level

JB: Jarque-Bera test of null hypothesis of normality in the residuals

AR: Test of null hypothesis of serial independence for the residuals

ARCH: Test of null hypothesis of constant variance of the residuals

GUM: General Unrestricted Model

SER-GUM: Standard error of the regression associated with the General Unrestricted Model

SER-Spec: Standard error of the regression associated with the Specific Model

Par-GUM: Number of parameters in the General Unrestricted Model

Par-Spec: Number of parameters estimated in the Specific Model

Max-Lag in Spec: Maximum lag-length in the Specific Model

Y: One cannot reject the associated null hypothesis

$\mathrm{N}$ : One cannot accept the associated null hypothesis

e: Automated specification excludes this variable

Na: Not Applicable because of insufficient degrees of freedom. 


\section{Transportation}

Exports: The estimates are largely invariant to changes in lag lengths or in estimation methods (figure A4 top; table A7). However, changes in the search strategy have sizeable effects on the price elasticity, regardless of whether one uses OLS or instrumental variables. For example, the OLS estimate of the price elasticity based on 4 lags and no search is -0.6 (insignificant) whereas reliance on a conservative automated search lowers the price elasticity to -0.11 but makes it statistically significant.

Imports: Estimates of the price inelasticity are particularly sensitive to changes in design (figure A4 bottom; table A8). For example, the only case of a negative price elasticity is the case of six lags with OLS and automated specification search. Again, in the absence of such automated search, the inference would be that the United States does not have suitable substitutes for foreign transportation services. 
Figure A4: Long-run Income and Price Elasticities for Aggregate Exports and Imports of Transportation Services - 1987-2001 Alternative Estimation Methods and Automated Specification Algorithms
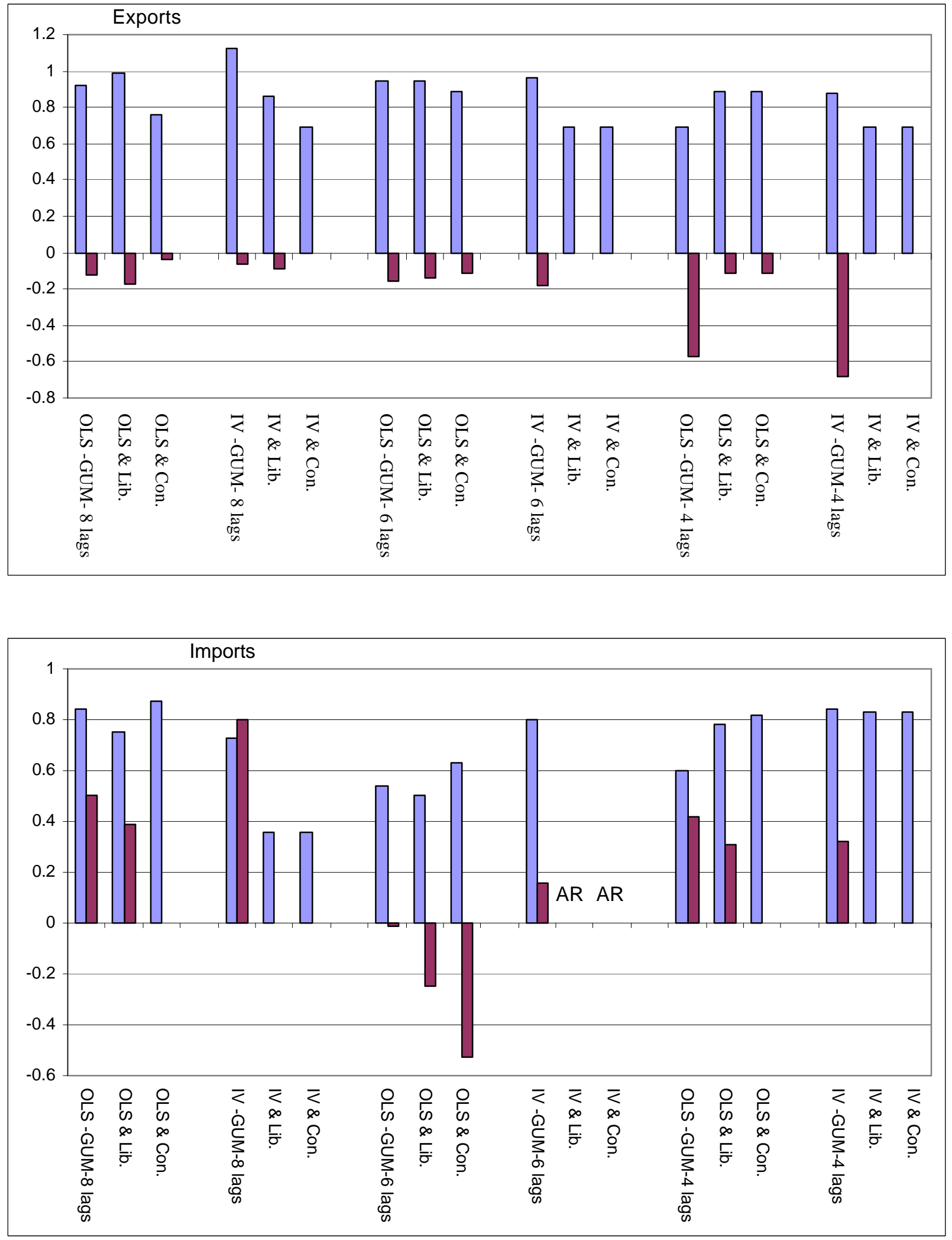

AR: Autoregressive Specification

GUM: General Unrestricted Model

Lib.: Liberal specification strategy

Con.: Conservative specification strategy 
Table A7: Long-run Income and Price Elasticities for Exports of Transportation - 1987-2001

Alternative Estimation Methods and Automated Specification Algorithms

\begin{tabular}{|c|c|c|c|c|c|c|c|c|c|c|c|}
\hline Lags & Method & Income & $\begin{array}{l}\text { Own- } \\
\text { Price }\end{array}$ & JB & AR & $\mathrm{ARCH}$ & $\begin{array}{c}\text { SER- } \\
\text { GUM }(\%)\end{array}$ & $\begin{array}{c}\text { SER- } \\
\text { Spec }(\%)\end{array}$ & $\begin{array}{l}\text { Par- } \\
\text { GUM }\end{array}$ & $\begin{array}{l}\text { Par- } \\
\text { Spec }\end{array}$ & $\begin{array}{l}\text { Max Lag } \\
\text { in Spec }\end{array}$ \\
\hline \multirow[t]{6}{*}{8} & OLS \& GUM & $0.92 *$ & -0.12 & $\mathrm{Y}$ & $\mathrm{Y}$ & $\mathrm{Y}$ & 2.24 & 2.24 & 28 & 28 & 8 \\
\hline & \multirow{2}{*}{$\begin{array}{l}\text { OLS \& Lib. Search } \\
\text { OLS \& Con. Search }\end{array}$} & $0.99 *$ & $-0.17 *$ & $\mathrm{Y}$ & $\mathrm{Y}$ & $\mathrm{Y}$ & 2.24 & 2.08 & 28 & 11 & 8 \\
\hline & & $0.76^{*}$ & -0.04 & $\mathrm{Y}$ & $\mathrm{Y}$ & $\mathrm{Y}$ & 2.24 & 2.19 & 28 & 8 & 7 \\
\hline & IV \& GUM & $1.12 *$ & -0.06 & $\mathrm{Y}$ & $\mathrm{Y}$ & $\mathrm{Y}$ & 2.78 & 2.78 & 28 & 28 & 8 \\
\hline & IV \& Lib. Search & $0.86^{*}$ & $-0.09 *$ & $\mathrm{Y}$ & Y & $\mathrm{Y}$ & 2.78 & 2.33 & 28 & 8 & 8 \\
\hline & IV \& Con. Search & $0.69 *$ & $0.00 \mathrm{e}$ & $\mathrm{Y}$ & $\mathrm{Y}$ & $\mathrm{Y}$ & 2.78 & 2.84 & 28 & 3 & 2 \\
\hline \multirow[t]{6}{*}{6} & OLS \& GUM & $0.95 *$ & -0.16 & $\mathrm{Y}$ & $\mathrm{Y}$ & $\mathrm{Y}$ & 2.31 & 2.31 & 22 & 22 & 6 \\
\hline & \multirow{2}{*}{$\begin{array}{l}\text { OLS \& Lib. Search } \\
\text { OLS \& Con. Search }\end{array}$} & $0.95^{*}$ & -0.14 & $\mathrm{Y}$ & $\mathrm{Y}$ & $\mathrm{Y}$ & 2.31 & 2.21 & 22 & 10 & 6 \\
\hline & & $0.89 *$ & -0.11 & $\mathrm{Y}$ & $\mathrm{Y}$ & $\mathrm{Y}$ & 2.31 & 2.41 & 22 & 7 & 4 \\
\hline & IV \& GUM & $0.96^{*}$ & -0.18 & $\mathrm{Y}$ & $\mathrm{Y}$ & $\mathrm{Y}$ & 2.32 & 2.32 & 22 & 22 & 6 \\
\hline & IV \& Lib. Search & $0.69 *$ & $0.00 \mathrm{e}$ & $\mathrm{Y}$ & $\mathrm{Y}$ & $\mathrm{Y}$ & 2.32 & 2.63 & 22 & 5 & 4 \\
\hline & IV \& Con. Search & $0.69 *$ & $0.00 \mathrm{e}$ & $\mathrm{Y}$ & $\mathrm{Y}$ & $\mathrm{Y}$ & 2.32 & 2.63 & 22 & 5 & 4 \\
\hline \multirow[t]{6}{*}{4} & \multirow{3}{*}{$\begin{array}{r}\text { OLS \& GUM } \\
\text { OLS \& Lib. Search } \\
\text { OLS \& Con. Search }\end{array}$} & $0.69 *$ & -0.57 & $\mathrm{Y}$ & Y & $\mathrm{Y}$ & 2.44 & 2.44 & 16 & 16 & 4 \\
\hline & & $0.89 *$ & -0.11 & $\mathrm{Y}$ & $\mathrm{Y}$ & $\mathrm{Y}$ & 2.44 & 2.41 & 16 & 7 & 4 \\
\hline & & $0.89 *$ & -0.11 & $\mathrm{Y}$ & $\mathrm{Y}$ & $\mathrm{Y}$ & 2.44 & 2.41 & 16 & 7 & 4 \\
\hline & \multirow{3}{*}{$\begin{array}{r}\text { IV \& GUM } \\
\text { IV \& Lib. Search } \\
\text { IV \& Con. Search } \\
\end{array}$} & 0.88 & -0.68 & $\mathrm{Y}$ & $\mathrm{Y}$ & $\mathrm{Y}$ & 2.62 & 2.62 & 16 & 16 & 4 \\
\hline & & $0.69 *$ & $0.00 \mathrm{e}$ & $\mathrm{Y}$ & Y & $\mathrm{Y}$ & 2.62 & 2.62 & 16 & 5 & 4 \\
\hline & & $0.69 *$ & $0.00 \mathrm{e}$ & $\mathrm{Y}$ & $\mathrm{Y}$ & $\mathrm{Y}$ & 2.62 & 2.79 & 16 & 3 & 2 \\
\hline & & & & \multicolumn{6}{|c|}{ FIML: Number of lags in the VAR } & & \\
\hline & & & & \multicolumn{2}{|c|}{8} & 6 & 4 & \multicolumn{2}{|c|}{2} & & \\
\hline & \multicolumn{3}{|c|}{ Income Elasticity } & \multicolumn{2}{|c|}{$1.05^{*}$} & $1.08 *$ & $0.95^{*}$ & \multicolumn{2}{|c|}{$0.85 *$} & & \\
\hline & \multirow{2}{*}{\multicolumn{3}{|c|}{$\begin{array}{l}\text { Own-Price Elasticity } \\
\text { Loading Coefficient }\end{array}$}} & \multicolumn{2}{|c|}{-0.10} & -0.28 & $-0.53 *$ & \multicolumn{2}{|c|}{-0.04} & & \\
\hline & & & & & & -0.07 & $-0.09 *$ & & & & \\
\hline & No. C & ointegrati & vectors & & & 1 & 1 & & & & \\
\hline & JB & & & & & $\mathrm{Y}$ & $\mathrm{Y}$ & & & & \\
\hline & $\mathrm{AR}$ & & & & & $\mathrm{Y}$ & $\mathrm{Y}$ & & & & \\
\hline & $\mathrm{ARC}$ & & & & & $\mathrm{Y}$ & $\mathrm{Y}$ & & & & \\
\hline
\end{tabular}

*Statistically significant at the 5 percent level

JB: Jarque-Bera test of null hypothesis of normality in the residuals

AR: Test of null hypothesis of serial independence for the residuals

ARCH: Test of null hypothesis of constant variance of the residuals

GUM: General Unrestricted Model

SER-GUM: Standard error of the regression associated with the General Unrestricted Model

SER-Spec: Standard error of the regression associated with the Specific Model

Par-GUM: Number of parameters in the General Unrestricted Model

Par-Spec: Number of parameters estimated in the Specific Model

Max-Lag in Spec: Maximum lag-length in the Specific Model

Y: One cannot reject the associated null hypothesis

$\mathrm{N}$ : One cannot accept the associated null hypothesis

e: Automated specification excludes this variable

Na: Not Applicable because of insufficient degrees of freedom. 
Table A8: Long-run Income and Price Elasticities for Imports of Transportation- 1987-2001 Alternative Estimation Methods and Automated Specification Algorithms

\begin{tabular}{|c|c|c|c|c|c|c|c|c|c|c|c|}
\hline Lags & Method & Income & $\begin{array}{l}\text { Own- } \\
\text { Price }\end{array}$ & JB & $\mathrm{AR}$ & $\mathrm{ARCH}$ & $\begin{array}{c}\text { SER- } \\
\text { GUM(\%) }\end{array}$ & $\begin{array}{l}\text { SER- } \\
\text { Spec } \\
(\%)\end{array}$ & $\begin{array}{l}\text { Par- } \\
\text { GUM }\end{array}$ & $\begin{array}{l}\text { Par- } \\
\text { Spec }\end{array}$ & $\begin{array}{l}\text { Max Lag } \\
\text { in Spec }\end{array}$ \\
\hline \multirow[t]{6}{*}{8} & OLS \& GUM & $0.84 *$ & $+0.50^{*}$ & $\mathrm{Y}$ & Y & $\mathrm{Y}$ & 2.74 & 2.74 & 29 & 29 & 8 \\
\hline & OLS \& Lib. Search & $0.79 *$ & $+0.28 *$ & $\mathrm{Y}$ & $\mathrm{Y}$ & $\mathrm{Y}$ & 2.74 & 2.52 & 29 & 6 & 6 \\
\hline & OLS \& Con. Search & $0.87 *$ & $0.00 \mathrm{e}$ & $\mathrm{Y}$ & $\mathrm{Y}$ & $\mathrm{Y}$ & 2.74 & 2.68 & 29 & 3 & 5 \\
\hline & IV \& GUM & 0.73 & 0.80 & $\mathrm{Y}$ & $\mathrm{Y}$ & $\mathrm{Y}$ & 3.04 & 3.04 & 29 & 29 & 8 \\
\hline & IV \& Lib. Search & $0.36 *$ & $0.00 \mathrm{e}$ & $\mathrm{Y}$ & $\mathrm{Y}$ & $\mathrm{Y}$ & 3.04 & 2.55 & 29 & 3 & 8 \\
\hline & IV \& Con. Search & $0.36^{*}$ & $0.00 \mathrm{e}$ & $\mathrm{Y}$ & $\mathrm{Y}$ & $\mathrm{Y}$ & 3.04 & 2.66 & 29 & 3 & 1 \\
\hline \multirow[t]{6}{*}{6} & OLS \& GUM & $0.54 *$ & -0.01 & $\mathrm{Y}$ & $\mathrm{Y}$ & $\mathrm{Y}$ & 2.62 & 2.62 & 23 & 23 & 6 \\
\hline & OLS \& Lib. Search & $0.50 *$ & $-0.25^{*}$ & $\mathrm{Y}$ & $\mathrm{Y}$ & $\mathrm{Y}$ & 2.62 & 2.42 & 23 & 7 & 6 \\
\hline & OLS \& Con. Search & $0.65 *$ & $-0.53 *$ & $\mathrm{Y}$ & $\mathrm{Y}$ & $\mathrm{Y}$ & 2.62 & 2.68 & 23 & 3 & 5 \\
\hline & IV \& GUM & $0.80 *$ & 0.16 & $\mathrm{Y}$ & $\mathrm{Y}$ & $\mathrm{Y}$ & 4.48 & 4.48 & 23 & 23 & 6 \\
\hline & IV \& Lib. Search & $0.00 \mathrm{e}$ & $0.00 \mathrm{e}$ & Y & $\mathrm{Y}$ & $\mathrm{Y}$ & 4.48 & 2.88 & 23 & 1 & 1 \\
\hline & IV \& Con. Search & $0.00 \mathrm{e}$ & $0.00 \mathrm{e}$ & $\mathrm{Y}$ & $\mathrm{Y}$ & $\mathrm{Y}$ & 4.48 & 2.88 & 23 & 1 & 1 \\
\hline \multirow[t]{6}{*}{4} & OLS \& GUM & $0.60^{*}$ & 0.42 & $\mathrm{Y}$ & Y & $\mathrm{Y}$ & 2.74 & 2.74 & 17 & 17 & 4 \\
\hline & OLS \& Lib. Search & $0.78 *$ & $0.31 *$ & $\mathrm{Y}$ & Y & $\mathrm{Y}$ & 2.74 & 2.53 & 17 & 5 & 1 \\
\hline & OLS \& Con. Search & $0.82 *$ & $0.00 \mathrm{e}$ & $\mathrm{Y}$ & Y & $\mathrm{Y}$ & 2.74 & 2.62 & 17 & 3 & 1 \\
\hline & IV \& GUM & $0.84 *$ & 0.32 & $\mathrm{Y}$ & $\mathrm{Y}$ & $\mathrm{Y}$ & 3.98 & 3.98 & 17 & 17 & 4 \\
\hline & IV \& Lib. Search & $0.83^{*}$ & $0.00 \mathrm{e}$ & $\mathrm{Y}$ & $\mathrm{Y}$ & $\mathrm{Y}$ & 3.98 & 2.65 & 17 & 3 & 2 \\
\hline & IV \& Con. Search & $0.83^{*}$ & $0.00 \mathrm{e}$ & $\mathrm{Y}$ & Y & Y & 3.98 & 2.65 & 17 & 3 & 2 \\
\hline
\end{tabular}

\begin{tabular}{lcccc}
\hline & \multicolumn{4}{c}{ FIML: Number of lags in the VAR } \\
\hline & 8 & 6 & 4 & 2 \\
Income Elasticity & -0.37 & $0.87^{*}$ & $0.91^{*}$ & $0.91^{*}$ \\
Own-Price Elasticity & +2.45 & +0.20 & +0.30 & -0.14 \\
Loading Coefficient & $-0.06^{*}$ & -0.32 & -0.19 & -0.10 \\
No. Cointegration vectors & 2 & & & \\
JB & & & 0 & 1 \\
AR & $\mathrm{Y}$ & $\mathrm{Y}$ & $\mathrm{Y}$ & $\mathrm{N}$ \\
ARCH & $\mathrm{N}$ & $\mathrm{Y}$ & $\mathrm{Y}$ & $\mathrm{Y}$ \\
\hline
\end{tabular}

*Statistically significant at the 5 percent level

JB: Jarque-Bera test of null hypothesis of normality in the residuals

AR: Test of null hypothesis of serial independence for the residuals

ARCH: Test of null hypothesis of constant variance of the residuals

GUM: General Unrestricted Model

SER-GUM: Standard error of the regression associated with the General Unrestricted Model

SER-Spec: Standard error of the regression associated with the Specific Model

Par-GUM: Number of parameters in the General Unrestricted Model

Par-Spec: Number of parameters estimated in the Specific Model

Max-Lag in Spec: Maximum lag-length in the Specific Model

Y: One cannot reject the associated null hypothesis

$\mathrm{N}$ : One cannot accept the associated null hypothesis

e: Automated specification excludes this variable

Na: Not Applicable because of insufficient degrees of freedom. 


\section{Travel}

Exports: For estimates based on four lags, the estimates show a narrow range of variation across estimation methods and search strategies (figure A5 top; table A9). These results suggest that simultaneity biases are small and that reliance on automated search make little difference for inference. The exception is the case of IV estimation with six lags: reliance on automated search yields either a time-series formulation or one with a positive price elasticity.

Imports: The estimates show a narrow range of variation across the estimation methods, lag lengths, and the search strategies (figure A5 bottom; table A10). This narrow range is the more interesting given that simplification of the general model with eight lags yields a specific formulation also with eight lags. 
Figure A5: Long-run Income and Price Elasticities for Aggregate Exports and Imports of Travel Services - 1987-2001 Alternative Estimation Methods and Automated Specification Algorithms
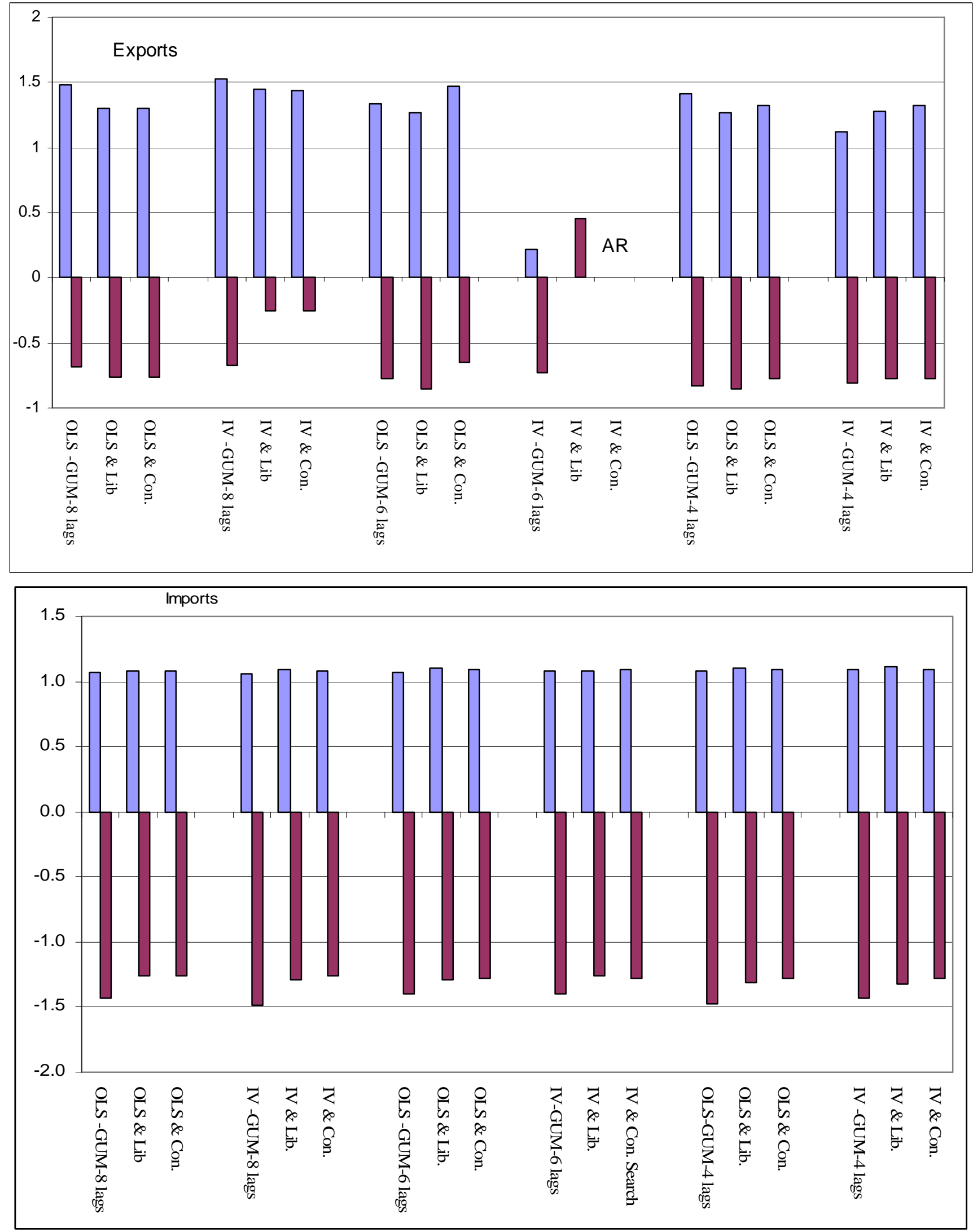

AR: Autoregressive Specification

GUM: General Unrestricted Model

Lib.: Liberal specification strategy

Con.: Conservative specification strategy 
Table A9: Long-run Income and Price Elasticities for Exports of Travel - 1987-2001

Alternative Estimation Methods and Automated Specification Algorithms

\begin{tabular}{|c|c|c|c|c|c|c|c|c|c|c|c|}
\hline Lags & Method & Income & $\begin{array}{l}\text { Own- } \\
\text { Price }\end{array}$ & JB & AR & $\mathrm{ARCH}$ & $\begin{array}{c}\text { SER- } \\
\text { GUM(\%) }\end{array}$ & $\begin{array}{l}\text { SER- } \\
\text { Spec } \\
(\%)\end{array}$ & $\begin{array}{l}\text { Par- } \\
\text { GUM }\end{array}$ & $\begin{array}{l}\text { Par- } \\
\text { Spec }\end{array}$ & $\begin{array}{l}\text { Max Lag } \\
\text { in Spec }\end{array}$ \\
\hline \multirow[t]{6}{*}{8} & OLS \& GUM & $1.48^{*}$ & $-0.68 *$ & $\mathrm{Y}$ & $\mathrm{Y}$ & $\mathrm{Y}$ & 4.17 & 4.17 & 27 & 27 & 8 \\
\hline & OLS \& Lib. Search & $1.30^{*}$ & $-0.76^{*}$ & $\mathrm{Y}$ & $\mathrm{Y}$ & $\mathrm{Y}$ & 4.17 & 3.48 & 27 & 4 & 8 \\
\hline & OLS \& Con. Search & $1.30^{*}$ & $-0.76^{*}$ & Y & $\mathrm{Y}$ & $\mathrm{Y}$ & 4.17 & 3.48 & 27 & 4 & 8 \\
\hline & IV \& GUM & $1.53^{*}$ & $-0.67 *$ & $\mathrm{Y}$ & $\mathrm{Y}$ & $\mathrm{Y}$ & 4.19 & 4.19 & 27 & 27 & 8 \\
\hline & IV \& Lib. Search & $1.45^{*}$ & $-0.26^{*}$ & $\mathrm{Y}$ & $\mathrm{Y}$ & $\mathrm{Y}$ & 4.19 & 3.58 & 27 & 5 & 8 \\
\hline & IV \& Con. Search & $1.44^{*}$ & $-0.26^{*}$ & $\mathrm{Y}$ & $\mathrm{Y}$ & $\mathrm{Y}$ & 4.19 & 3.58 & 27 & 5 & 8 \\
\hline \multirow[t]{6}{*}{6} & OLS \& GUM & $1.34 *$ & $-0.78 *$ & $\mathrm{Y}$ & $\mathrm{Y}$ & $\mathrm{Y}$ & 4.00 & 4.00 & 21 & 21 & 6 \\
\hline & OLS \& Lib. Search & $1.27 *$ & $-0.85^{*}$ & $\mathrm{Y}$ & $\mathrm{Y}$ & $\mathrm{Y}$ & 4.00 & 3.66 & 21 & 4 & 4 \\
\hline & OLS \& Con. Search & $1.47 *$ & $-0.65^{*}$ & $\mathrm{Y}$ & $\mathrm{Y}$ & $\mathrm{Y}$ & 4.00 & 3.87 & 21 & 4 & 2 \\
\hline & IV \& GUM & 0.22 & $-0.73 *$ & $\mathrm{Y}$ & Y & $\mathrm{Y}$ & 5.47 & 5.47 & 21 & 21 & 6 \\
\hline & IV \& Lib. Search & $0.00 \mathrm{e}$ & $+0.46^{*}$ & $\mathrm{Y}$ & $\mathrm{Y}$ & $\mathrm{Y}$ & 5.47 & 4.85 & 21 & 3 & 2 \\
\hline & IV \& Con. Search & $0.00 \mathrm{e}$ & $0.00 \mathrm{e}$ & $\mathrm{Y}$ & $\mathrm{Y}$ & Y & 5.47 & 4.35 & 21 & 2 & 2 \\
\hline \multirow[t]{6}{*}{4} & OLS \& GUM & $1.41 *$ & $-0.83^{*}$ & $\mathrm{Y}$ & $\mathrm{Y}$ & $\mathrm{Y}$ & 3.85 & 3.85 & 15 & 15 & 4 \\
\hline & OLS \& Lib. Search & $1.27^{*}$ & $-0.85^{*}$ & Y & $\mathrm{Y}$ & $\mathrm{Y}$ & 3.85 & 3.66 & 15 & 4 & 4 \\
\hline & OLS \& Con. Search & $1.32 *$ & $-0.77 *$ & $\mathrm{Y}$ & Y & $\mathrm{Y}$ & 3.85 & 3.76 & 15 & 4 & 3 \\
\hline & IV \& GUM & $1.12^{*}$ & $-0.81 *$ & Y & $\mathrm{Y}$ & $\mathrm{Y}$ & 4.35 & 4.35 & 15 & 15 & 4 \\
\hline & IV \& Lib. Search & $1.28 *$ & $-0.78 *$ & $\mathrm{Y}$ & $\mathrm{Y}$ & $\mathrm{Y}$ & 4.35 & 3.65 & 15 & 5 & 3 \\
\hline & IV \& Con. Search & $1.32 *$ & $-0.77 *$ & $\mathrm{Y}$ & Y & Y & 4.35 & 3.76 & 15 & 4 & 3 \\
\hline
\end{tabular}

\begin{tabular}{lcccc}
\hline & \multicolumn{4}{c}{ FIML: Number of lags in the VAR } \\
\hline & 8 & 6 & 4 & 2 \\
Income Elasticity & $1.30^{*}$ & $1.57^{*}$ & $1.20^{*}$ & $0.85^{*}$ \\
Own-Price Elasticity & $-0.77^{*}$ & $-0.79^{*}$ & $-0.96^{*}$ & $-0.76^{*}$ \\
Loading Coefficient & $-0.32^{*}$ & $-0.20^{*}$ & $-0.35^{*}$ & -0.16 \\
& & & & \\
No. Cointegration vectors & 2 & 1 & 0 & 0 \\
JB & & & & \\
AR & $\mathrm{Y}$ & $\mathrm{Y}$ & $\mathrm{Y}$ & $\mathrm{Y}$ \\
ARCH & $\mathrm{Y}$ & $\mathrm{Y}$ & $\mathrm{Y}$ & $\mathrm{Y}$ \\
& $\mathrm{Na}$ & $\mathrm{Y}$ & $\mathrm{Y}$ & $\mathrm{Y}$ \\
\hline
\end{tabular}

*Statistically significant at the 5 percent level

JB: Jarque-Bera test of null hypothesis of normality in the residuals

AR: Test of null hypothesis of serial independence for the residuals

ARCH: Test of null hypothesis of constant variance of the residuals

GUM: General Unrestricted Model

SER-GUM: Standard error of the regression associated with the General Unrestricted Model

SER-Spec: Standard error of the regression associated with the Specific Model

Par-GUM: Number of parameters in the General Unrestricted Model

Par-Spec: Number of parameters estimated in the Specific Model

Max-Lag in Spec: Maximum lag-length in the Specific Model

Y: One cannot reject the associated null hypothesis

$\mathrm{N}$ : One cannot accept the associated null hypothesis

e: Automated specification excludes this variable

Na: Not Applicable because of insufficient degrees of freedom. 
Table A10: Long-run Income and Price Elasticities for Imports of Travel - 1987-2001

Alternative Estimation Methods and Automated Specification Algorithms

\begin{tabular}{|c|c|c|c|c|c|c|c|c|c|c|c|}
\hline Lags & Method & Income & $\begin{array}{l}\text { Own- } \\
\text { Price }\end{array}$ & JB & AR & $\mathrm{ARCH}$ & $\begin{array}{c}\text { SER- } \\
\text { GUM(\%) }\end{array}$ & $\begin{array}{l}\text { SER- } \\
\text { Spec } \\
(\%)\end{array}$ & $\begin{array}{l}\text { Par- } \\
\text { GUM }\end{array}$ & $\begin{array}{l}\text { Par- } \\
\text { Spec }\end{array}$ & $\begin{array}{l}\text { Max Lag } \\
\text { in Spec }\end{array}$ \\
\hline \multirow[t]{6}{*}{8} & OLS \& GUM & $1.07 *$ & $-1.43 *$ & $\mathrm{Y}$ & $\mathrm{Y}$ & $\mathrm{Y}$ & 2.29 & 2.29 & 27 & 27 & 8 \\
\hline & OLS \& Lib. Search & $1.08^{*}$ & $-1.26^{*}$ & $\mathrm{Y}$ & $\mathrm{Y}$ & $\mathrm{Y}$ & 2.29 & 2.13 & 27 & 7 & 7 \\
\hline & OLS \& Con. Search & $1.08 *$ & $-1.26 *$ & $\mathrm{Y}$ & $\mathrm{Y}$ & $\mathrm{Y}$ & 2.29 & 2.22 & 27 & 5 & 7 \\
\hline & IV \& GUM & $1.06^{*}$ & $-1.48 *$ & $\mathrm{Y}$ & $\mathrm{Y}$ & $\mathrm{Y}$ & 2.35 & 2.35 & 27 & 27 & 8 \\
\hline & IV \& Lib. Search & $1.09^{*}$ & $-1.29 *$ & $\mathrm{Y}$ & $\mathrm{Y}$ & $\mathrm{Y}$ & 2.35 & 2.02 & 27 & 11 & 8 \\
\hline & IV \& Con. Search & $1.08 *$ & $-1.26 *$ & $\mathrm{Y}$ & $\mathrm{Y}$ & $\mathrm{Y}$ & 2.35 & 2.23 & 27 & 5 & 7 \\
\hline \multirow[t]{6}{*}{6} & OLS \& GUM & $1.07 *$ & $-1.40 *$ & $\mathrm{Y}$ & $\mathrm{Y}$ & $\mathrm{Y}$ & 2.24 & 2.24 & 21 & 21 & 6 \\
\hline & OLS \& Lib. Search & $1.10^{*}$ & $-1.29 *$ & $\mathrm{Y}$ & $\mathrm{Y}$ & $\mathrm{Y}$ & 2.24 & 2.16 & 21 & 7 & 6 \\
\hline & OLS \& Con. Search & $1.09 *$ & $-1.28 *$ & $\mathrm{Y}$ & $\mathrm{Y}$ & $\mathrm{Y}$ & 2.24 & 2.35 & 21 & 4 & 4 \\
\hline & IV \& GUM & $1.08^{*}$ & $-1.40 *$ & $\mathrm{Y}$ & $\mathrm{Y}$ & $\mathrm{Y}$ & 2.28 & 2.28 & 21 & 21 & 6 \\
\hline & IV \& Lib. Search & $1.08 *$ & $-1.26^{*}$ & $\mathrm{Y}$ & $\mathrm{Y}$ & $\mathrm{Y}$ & 2.28 & 2.13 & 21 & 8 & 6 \\
\hline & IV \& Con. Search & $1.09 *$ & $-1.28 *$ & $\mathrm{Y}$ & $\mathrm{Y}$ & $\mathrm{Y}$ & 2.28 & 2.35 & 21 & 4 & 4 \\
\hline \multirow[t]{6}{*}{4} & OLS \& GUM & $1.08^{*}$ & $-1.47 *$ & $\mathrm{Y}$ & $\mathrm{Y}$ & $\mathrm{Y}$ & 2.41 & 2.41 & 15 & 15 & 4 \\
\hline & OLS \& Lib. Search & $1.10^{*}$ & $-1.31 *$ & $\mathrm{Y}$ & $\mathrm{Y}$ & $\mathrm{Y}$ & 2.41 & 2.30 & 15 & 5 & 4 \\
\hline & OLS \& Con. Search & $1.09 *$ & $-1.28^{*}$ & $\mathrm{Y}$ & $\mathrm{Y}$ & $\mathrm{Y}$ & 2.41 & 2.35 & 15 & 4 & 4 \\
\hline & IV \& GUM & $1.09 *$ & $-1.43^{*}$ & Y & $\mathrm{Y}$ & $\mathrm{Y}$ & 2.45 & 2.45 & 15 & 15 & 4 \\
\hline & IV \& Lib. Search & $1.11^{*}$ & $-1.32 *$ & $\mathrm{Y}$ & $\mathrm{Y}$ & $\mathrm{Y}$ & 2.45 & 2.28 & 15 & 5 & 4 \\
\hline & IV \& Con. Search & $1.09 *$ & $-1.28 *$ & $\mathrm{Y}$ & $\mathrm{Y}$ & Y & 2.45 & 2.35 & 15 & 4 & 4 \\
\hline
\end{tabular}

\begin{tabular}{lcccc}
\hline & \multicolumn{5}{c}{ FIML: Number of lags in the VAR } \\
\hline & 8 & 6 & 4 & 2 \\
Income Elasticity & $1.08^{*}$ & $1.05^{*}$ & $1.04^{*}$ & $0.86^{*}$ \\
Own-Price Elasticity & $-1.63^{*}$ & $-1.45^{*}$ & $-1.56^{*}$ & $-1.98^{*}$ \\
Loading Coefficient & $-0.85^{*}$ & $-1.19^{*}$ & $-0.82^{*}$ & -0.11 \\
No. Cointegration vectors & & & & \\
JB & & 1 & 1 & 2 \\
AR & & & & \\
ARCH & Y & Y & Y & Y \\
\hline
\end{tabular}

*Statistically significant at the 5 percent level

JB: Jarque-Bera test of null hypothesis of normality in the residuals

AR: Test of null hypothesis of serial independence for the residuals

ARCH: Test of null hypothesis of constant variance of the residuals

GUM: General Unrestricted Model

SER-GUM: Standard error of the regression associated with the General Unrestricted Model

SER-Spec: Standard error of the regression associated with the Specific Model

Par-GUM: Number of parameters in the General Unrestricted Model

Par-Spec: Number of parameters estimated in the Specific Model

Max-Lag in Spec: Maximum lag-length in the Specific Model

Y: One cannot reject the associated null hypothesis

$\mathrm{N}$ : One cannot accept the associated null hypothesis

Na: Not Applicable because of insufficient degrees of freedom. 

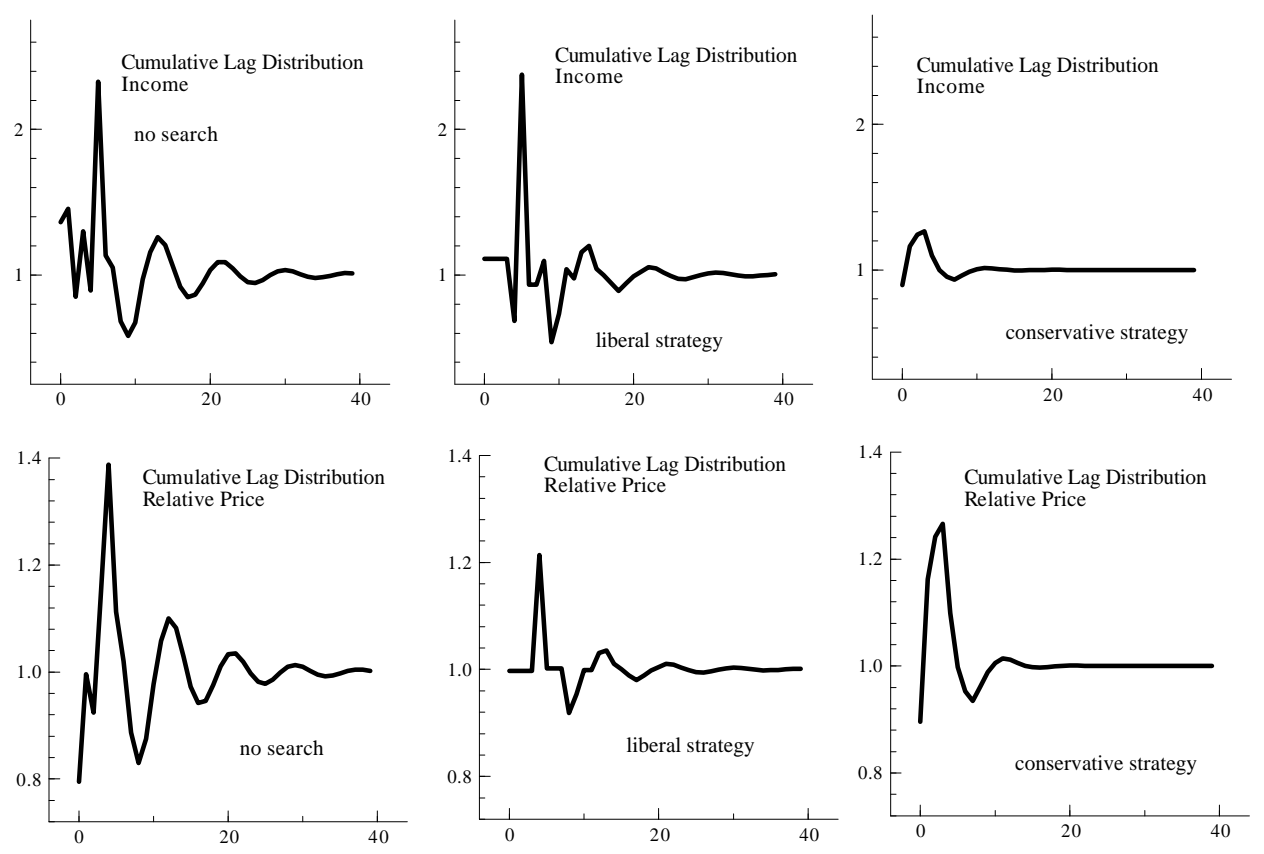

Figure A6: Cumulative Lag Distribution for OLS Elasticities of Travel Imports - 6 lags
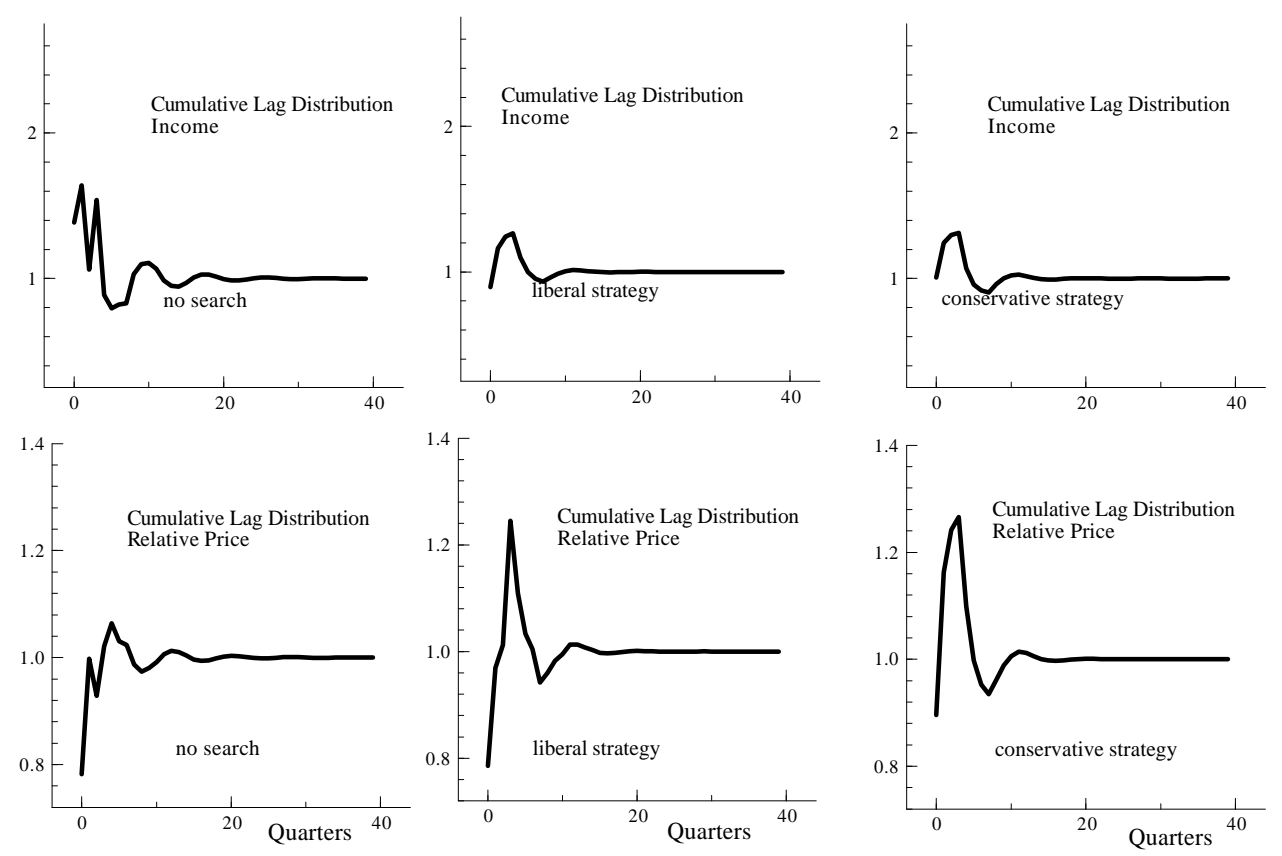

Figure A7: Cumulative Lag Distribution for OLS Elasticities of Travel Imports - 4 lags 


\section{Aggregation Biases}

I compute the aggregate of income elasticities for exports using equation (7); I also compute the corresponding aggregate for the price elasticities. The results indicate that the income elasticity of the aggregate equation is always lower than the aggregate of the income elasticities from the disaggregated equations (figure A8). In other words, aggregation is biasing the income elasticity downwards, though the magnitude and significance of the biases is sensitive to the estimation method: the aggregation bias is significant only for FIML. For the price elasticity, the results indicate that the estimate based on the aggregate equation is significantly lower (in absolute terms) than the estimate based on the aggregation of price elasticities for service-specific categories (figure A9).

To compute the aggregate of income elasticities for imports I use equation (12); I also compute the corresponding aggregate for the price elasticities. The results indicate that the income elasticity of the aggregate equation is higher than the aggregate of the income elasticities from the disaggregated equations (figure A10). In other words, aggregation is biasing the income elasticity upwards. Again, the aggregation bias is significant only for FIML. For the price elasticity, the results indicate that the estimate for aggregate imports is significantly different from the estimate based on the aggregation of servicespecific categories (figure A11); the direction of the bias is sensitive to the estimation method. 

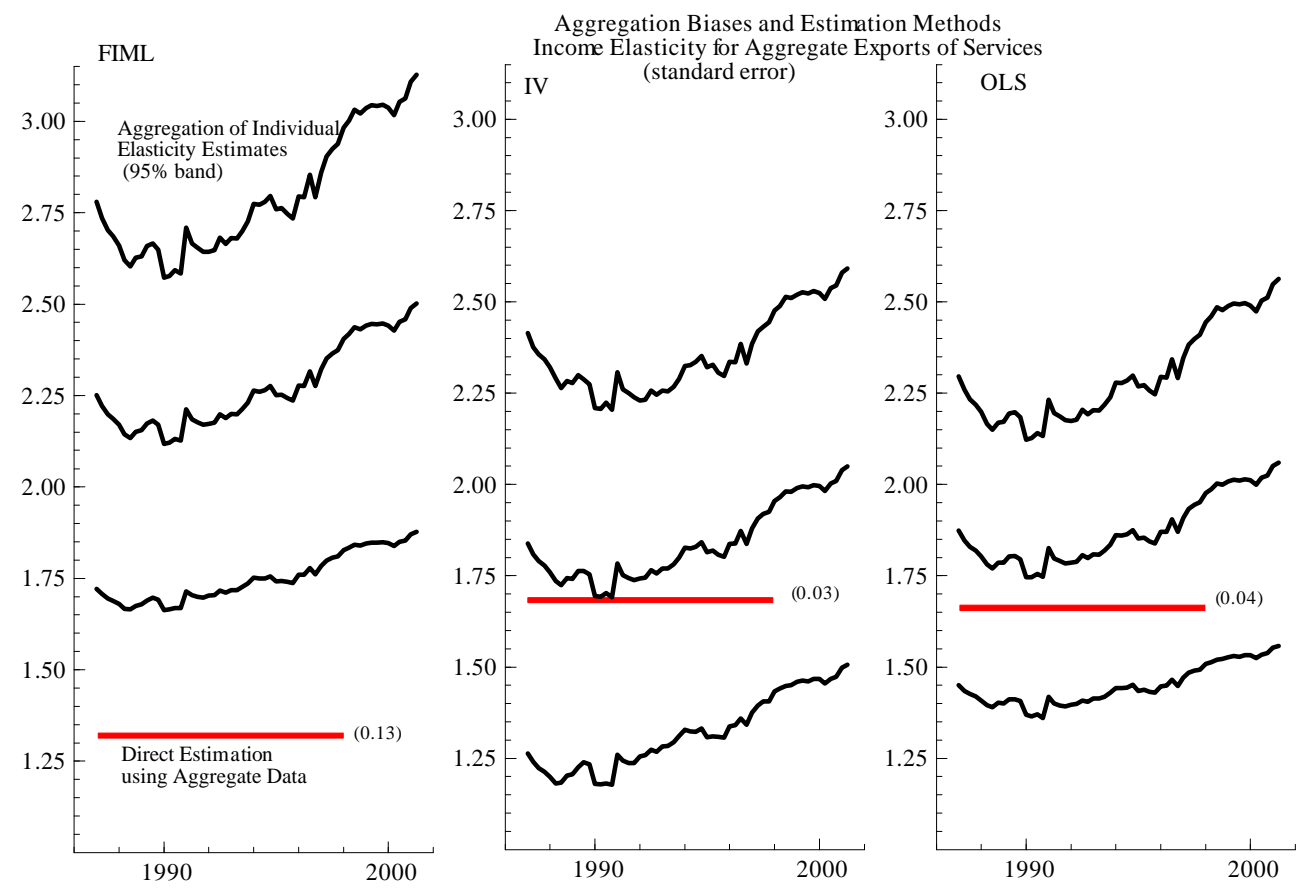

Figure A8
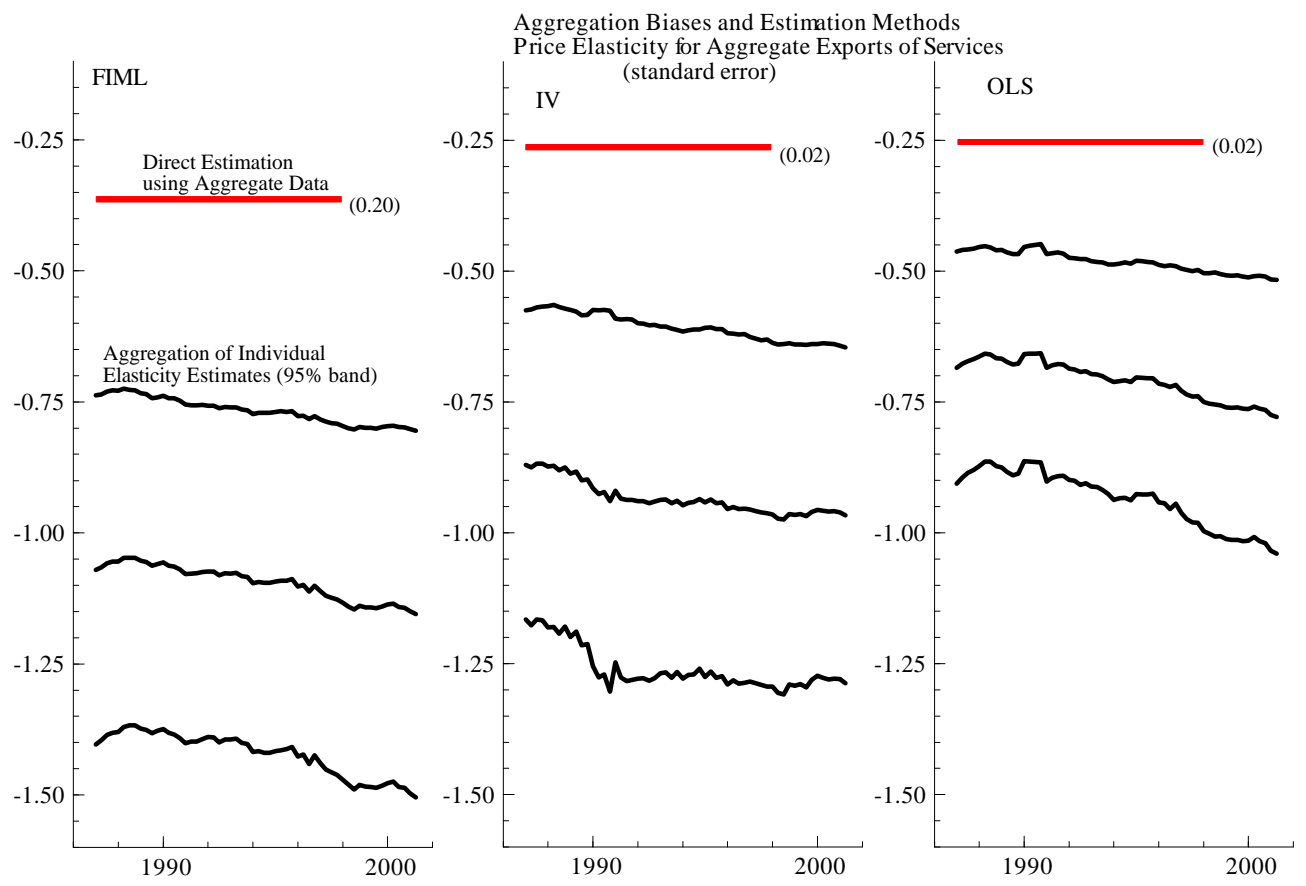

Figure A9 

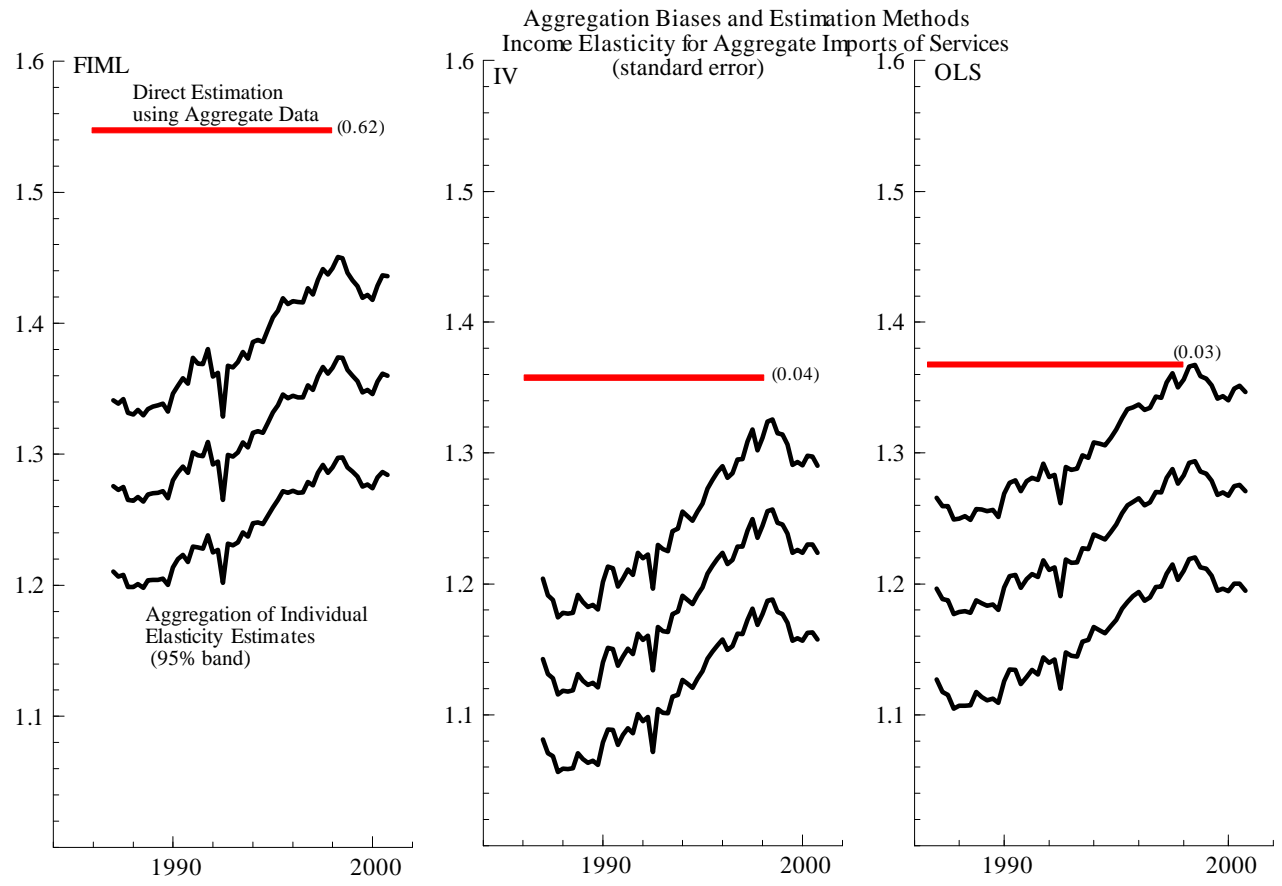

Figure A10
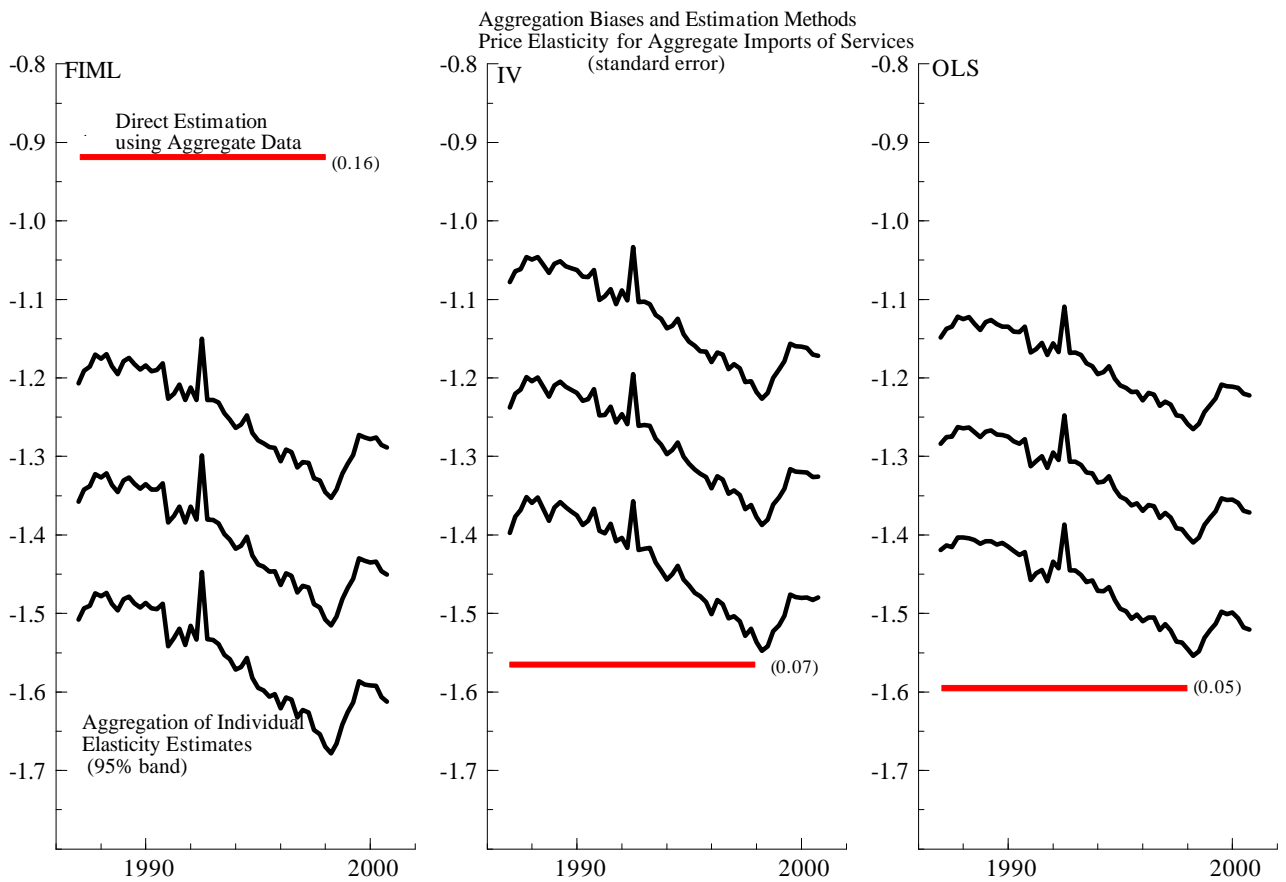

Figure A11 